Economia e Sociedade, Campinas, Unicamp. IE.

http://dx.doi.org/10.1590/1982-3533.2017v26n3art3

\title{
O debate sobre o processo de desenvolvimento econômico da Coreia do Sul: uma linha alternativa de interpretação *
}

\author{
Uallace Moreira Lima *
}

\begin{abstract}
Resumo
A Coreia do Sul apresentou alto e rápido crescimento econômico entre os anos 1960 e 1980, associado a um upgrading em seu parque industrial e forte inserção no comércio internacional. Três correntes teóricas têm destaque na interpretação dos motivos que levaram a Coreia ao sucesso: 1) os autores do mainstream economics, defensores dos princípios de mercado; 2) a corrente heterodoxa endogenista que defende o papel do Estado como elemento central; 3) a terceira linha defende que o cenário externo é o principal motivo para o sucesso da Coreia. Neste artigo, desdobra-se uma hipótese central da Escola da Unicamp, defendendo a hipótese de que o avanço da economia coreana com profunda transformação estrutural e upgrading em seu comércio exterior foi possível em um contexto externo inicialmente favorável, em decorrência de um conjunto de características históricas que a diferenciaram de outras economias de industrialização tardia nos aspectos da política interna.
\end{abstract}

Palavras-chave: Desenvolvimento Econômico; Industrialização tardia; Estado; Coreia do Sul; Política econômica.

\section{Abstract \\ The debate on the economic development process of South Korea: an alternative line of interpretation}

South Korea showed high and rapid economic growth particularly between 1960 and 1980 along with an upgrading of its industrial park and strong insertion into international trade. There are three major theoretical perspectives which provide interpretations of the reasons that led Korea to succeed: 1) Supporters of mainstream economics - defenders of market principles; 2) the current endogenous heterodox defending the state's role as a central element; 3) the third perspective claims that the external scenario is the main reason for Korea's success. In this article, a central hypothesis is developed - based upon the economic fundamentals of the Unicamp School of thought - defending the hypothesis that

* Artigo recebido em 12 de outubro de 2015 e aprovado em 20 de março de 2017.

** Professor adjunto da Faculdade de Economia da Universidade Federal da Bahia (FE/UFBA), Salvador, BA, Brasil. E-mail: uallacemoreira@ hotmail.com.

Economia e Sociedade, Campinas, v. 26, n. 3 (61), p. 585-631, dez. 2017. 
the advancement of the Korean economy, their deep structural transformation and upgrading in foreign trade, was only possible because of an initially favorable external context due to a set of historical characteristics that distinguish them from other economies of late industrialization as to aspects of domestic policy.

Keywords: Economic development; Late industrialization; State; South Korea; Economic policy.

JEL N10, N15, O1, O2, O3.

\section{Introdução}

A Coreia do Sul apresentou alto e rápido crescimento econômico entre os anos 1960 e 1980. Essa expansão econômica esteve associada a um upgrading em seu parque industrial, assim como uma forte inserção no comércio internacional a partir dos anos 1970. A conjunção dessas transformações promoveu mudanças estruturais profundas, fazendo com que a Coreia passasse a ser um país visto como referencial de desenvolvimento econômico para outros países em desenvolvimento. As razões e origens do chamado "sucesso" coreano foram objeto de amplo debate, destacando-se principalmente: autores da escola neoclássica; defensores da corrente "heterodoxa endogenista; e a corrente do cenário externo favorável.

Neste artigo, embora seja importante reconhecer a contribuição da corrente neoclássica para o debate ao levantar questionamentos sobre as diferenças entre os modelos outward-looking - expor-led $e$ inwardlooking- import-substitution, refuta-se a interpretação de cunho neoclássico por considerar que ela tenha um caráter a-histórico, economicista e não ter correspondência com o que de fato aconteceu do ponto de vista empírico e teórico. Por outro lado, busca-se um meio-termo entre as condições internas e externas favoráveis, rejeitando a primazia de qualquer polo. Se for verdade que o cenário externo se mostrou favorável à Coreia do Sul, é inegável que a coesão entre Estado orientado por uma elite desenvolvimentista e oligopólios privados que aceitavam - e em certa medida influenciavam - a oferta de subsídios e a orientação estratégica estatal maximizou a oportunidade externa. Vale dizer o óbvio: a oportunidade não seria suficiente para induzir ao desenvolvimento industrial sem que ela fosse aproveitada. 
Com efeito, foram instituições públicas e privadas locais sustentadas por uma aliança estratégica entre a elite desenvolvimentista e a burguesia nacional que permitiram que a oportunidade fosse aproveitada e, ao longo do tempo, reiterada e mesmo alargada. Por exemplo, é provável que os governos dos Estados Unidos e do Japão tenham feito gestões junto a seus bancos privados para que não interrompessem o financiamento externo à Coreia durante a crise financeira global de 1982, mas a capacidade de geração de reservas cambiais por meio de exportações industriais afastava essa decisão bancária do tipo de ajuda a fundo perdido, uma característica da década de 1950, ou seja, os bancos fizeram um bom investimento que recuperaram rapidamente. Ademais, a capacidade de geração própria de reservas cambiais para pagar o passivo externo não pode ser explicada apenas pela abertura preferencial do mercado dos Estados Unidos e pelo licenciamento de tecnologias japonesas. Tanto mais porque as preferências comerciais foram sendo eliminadas na década de 1980 e substituídas por protecionismo crescente nos EUA, enquanto as corporações japonesas deixavam de licenciar tecnologias de ponta, uma vez que sofriam concorrência crescente de corporações coreanas capazes de gerar tecnologias autonomamente. Nada disso pode ser entendido sem conferir importância a determinantes locais do financiamento do investimento, aperfeiçoamento tecnológico e redução de custos, cujas raízes encontram-se na estrutura de propriedade do capital, centralização financeira e organização empresarial típicos da Coreia. A história econômica mundial é repleta de casos nacionais em que governantes, empresas e instituições locais não se mostraram capazes nem de aproveitar plenamente oportunidades externas nem reagir com sucesso a eventual piora do ambiente externo.

Ao afirmar isso, considera-se estar desdobrando uma hipótese central de obras clássicas da chamada Escola da Unicamp, segundo a qual a forma da transição e o modo de desenvolvimento do capitalismo é determinado, em última instância, pelo modo de inserção no sistema mundial e suas transformações, mas em primeira instância pelos esquemas locais de reprodução do capital (Mello, 1975) e também pelo encaminhamento das lutas sociais (Oliveira, 2002). 
A hipótese defendida aqui é que o avanço da economia coreana com profunda transformação estrutural e upgrading em seu comércio exterior foi possível dentro de um contexto externo inicialmente favorável, em decorrência de um conjunto de características históricas que a diferenciaram de outras economias de industrialização tardia, basicamente em quatro aspectos da política interna em relação a: 1) estrutura de propriedade do capital; 2) centralização financeira; 3) organização empresarial; 4) e absorção/desenvolvimento tecnológico. O cenário externo favorável à Coreia do Sul foi importante, mas não exclusivamente determinante para que o Estado conduzisse políticas de forma coesa com os interesses do país.

Alguns trabalhos utilizaram elementos da Escola de Campinas para interpretar o processo de desenvolvimento da Coreia, como os trabalhos de Canuto (1994) e Coutinho (1999). A partir da hipótese central das obras clássicas da Escola de Campinas, pretende-se demonstrar neste artigo uma coesão na condução das políticas internas em relação aos quatro fatores apontados no parágrafo anterior, mostrando as suas interrelações como elementos fundamentais para o sucesso da Coreia. Com isso, o artigo oferece uma nova perspectiva para o debate em relação a trajetória de desenvolvimento da Coreia ao analisar a conexão e essencialidade entre esses quatros fatores para a compreensão da trajetória de desenvolvimento econômica do país.

O artigo é dividido em três seções, além desta introdução. A primeira seção discute as principais ideias das três correntes teóricas que interpretam os motivos que levaram a Coreia do Sul ao rápido crescimento econômico e às mudanças estruturais. Na segunda seção faz-se uma síntese da evolução histórica da Coreia do Sul com o objetivo de apresentar os momentos em que o cenário externo foi favorável ao país. Na terceira seção, a fim de justificar e fortalecer a hipótese do artigo, discute-se a condução da política econômica levando em consideração a estrutura de propriedade do capital, organização empresarial, centralização do capital e o processo de absorção e desenvolvimento tecnológico. Na conclusão apresenta-se uma síntese das principais ideias do artigo e reafirma-se a hipótese defendida. 


\section{Uma revisão das principais correntes teóricas do debate sobre o desenvolvimento econômico da Coreia do Sul}

Há uma ampla bibliografia que discute os motivos do elevado crescimento e a profunda transformação estrutural que marcaram a Coreia do Sul entre os anos 1960 e 1980. No debate acerca da Coreia há três correntes que se destacam, quais sejam: a) a corrente de cunho neoclássica a qual defende a hipótese de que o sucesso da economia coreana tem origem em uma economia orientada pelos princípios do mercado, seguindo um modelo de desenvolvimento orientado para fora, o chamado export-led, sendo que o Estado tem uma presença ínfima apenas no sentido de criar um arcabouço institucional que promovesse o bom funcionamento do mercado. Entre os principais autores defensores desse pensamento estão Balassa (1982), Westphal e Kim (1982) e o Banco Mundial (1987) (1993); b) há uma segunda linha de pensamento heterodoxa endogenista que coloca o Estado como elemento central e o principal ator desse processo. Entre os principais autores dessa linha estão Alice Amsden (1989) e Chang (1994); c) a terceira linha de interpretação afirma que o cenário externo se mostrou sempre favorável ao país, criando assim as condições necessárias para que a Coreia alcançasse o chamado "sucesso". Entre os autores selecionados neste artigo que seguem essa conduta de interpretação estão Medeiros (1997) e Cho (2001).

Entre os estudos da corrente neoclássica, um dos principais trabalhos que se destaca no debate sobre a economia coreana é o de Balassa (1982). O autor analisa as estratégias de desenvolvimento de economias que ele chama de semi-industriais sob duas óticas: outwardlooking - expor-led e inward-looking - import-substitution. Essa classificação é realizada a partir da análise da política de incentivos e subsídios tanto para o mercado interno como para o comércio exterior. $\mathrm{O}$ autor atribui uma política de incentivos e subsídios para o estímulo ao mercado interno como uma política contrária às exportações. Na verdade, o modelo de orientação para fora está associado a uma política de promoção das exportações, enquanto o modelo de orientação para dentro está associado ao modelo de substituição de importações. Para o autor, ambos os modelos se contrapõem já que têm objetivos completamente diferentes. 
Segundo Balassa (1982), a Coreia do Sul está inserida em um conjunto de países que adotou a estratégia de substituição de importações e mercado protegido em um período muito curto, posteriormente implementando o modelo de desenvolvimento para fora, ou seja, a estratégia política de promoção das exportações. A Coreia do Sul, em meados dos anos 1960, adotou a estratégia de substituição de importações para completar o processo de industrialização fácil de bens de consumo não duráveis e de outras cadeias da produção responsáveis para oferta de insumo para esse ramo. Entretanto, já nos anos 1960, a Coreia tinha adotado políticas orientadas para fora e isso fica explícito na oferta de incentivos às exportações similares aos incentivos dados aos setores de substituição de importações, ao contrário de outros países que tiveram como estratégia única a substituição de importações como modelo de desenvolvimento.

Balassa (1982) afirma que a Coreia do Sul implementou um sistema de incentivos estável em um sistema de livre comércio, que beneficiou tanto as exportações como também as importações, com os exportadores tendo ampla liberdade de escolha entre insumos do mercado interno ou insumos importados, assim como a oferta de benefícios para os produtores de insumos nacionais disponíveis para a produção de produtos que seriam exportados. Para o autor, houve na Coreia um sistema de medidas de incentivos e subsídios para as exportações que incluíam crédito preferencial, redução de impostos diretos, etc. O sistema de incentivos para as exportações estava associado ao modelo de industrialização para fora, com as exportações sendo peça chave para o crescimento econômico. Com isso, a estratégia adotada na concessão de incentivos e subsídios para a promoção das exportações de manufaturas não discriminou as atividades primárias, contribuindo para que predominasse um processo de desenvolvimento econômico com uma expansão equilibrada entre os setores manufatureiros e primários.

Outro estudo que dá ênfase à adoção ao modelo de desenvolvimento voltado para fora com a política de promoção das exportações é de Westphal e Kim (1982). Assim como Balassa (1982), os autores afirmam que até o início dos anos 1960 a Coreia do Sul foi 
marcada pelo processo de substituição de importações do ramo de bens de consumo não duráveis e da indústria leve, com as exportações apresentando um baixo desempenho. Só a partir de meados dos anos 1960, com as reformas que promoveram o livre comércio, a Coreia iniciou uma nova trajetória do seu desenvolvimento com a adoção ao modelo de crescimento voltado para fora associado a uma política de promoção das exportações de manufaturas.

Para Westphal e Kim (1982), já no início do governo Park em meados dos anos 1960, começou o processo de liberalização da economia coreana que favoreceu a implementação de um novo modelo de desenvolvimento econômico, com as exportações passando a ser um elemento chave para o crescimento da economia. Uma das principais alterações provocadas pelas políticas de liberalização foi na política cambial, quando se extingue o regime múltiplo de câmbio. Além da reforma cambial, outras reformas alinhadas com o processo de liberalização foram sendo adotadas, tais como o relaxamento do controle das importações com a redução das quotas e licenças para as importações.

Aliada às reformas liberais, passa a predominar um consenso de que para o rápido crescimento da economia coreana seria necessário aderir a uma nova direção na política industrial orientada pelas exportações, implementando medidas de política de estímulo para as exportações de manufaturados. Nesse sentido, a Coreia passou a adotar várias medidas para promover as exportações como taxa de câmbio desvalorizada, política de tratamento preferencial para as exportações, crédito preferencial, além de subsídios e incentivos para as grandes empresas exportadoras com a exigência de metas de desempenho.

Pode parecer completamente contraditório os autores defenderem e relacionarem as reformas liberais com a estratégia de industrialização orientada pelas exportações, já que fica claro um amplo leque de políticas de estímulo. Entretanto, Westphal e Kim (1982) afirmam que as políticas de incentivos à industrialização orientada pelas exportações são perfeitamente compatíveis com o receituário liberal na medida em que não alteram os preços relativos do mercado, fazendo com que a Coreia do Sul seguisse a especialização industrializante e uma inserção no comércio 
exterior segundo as vantagens comparativas. Os autores sustentam seus argumentos mostrando que tais políticas não influenciaram no ganho de competitividade da Coreia do Sul, pois quando se compara o sistema de incentivos da Coreia com outros países, observa-se um nível de proteção e incentivos bem mais baixos do que outras nações ou de acordo com os padrões internacionais, ficando claro que na Coreia predominou uma zona livre de comércio.

Dois estudos do Banco Mundial têm destaque no debate acerca do sucesso da Coreia do Sul: o primeiro estudo foi publicado em 1987 e o outro em 1993. No primeiro documento, o argumento principal para afirmar que a Coreia seguiu as políticas "corretas" é que ao aderir ao regime de livre comércio, as várias medidas de incentivos da política intervencionista se auto cancelavam produzindo uma estrutura de incentivos neutra. A política de proteção de importações tinha efeito nulo e gerava um sistema de incentivos neutro já que havia a política de subsídios para as exportações, isto é, a política de proteção às importações (que gerava distorção de preços) resultante do modelo de substituição de importações, era neutralizada pela política de subsídios às exportações (que gerava o equilíbrio no sistema de preços) através do modelo de desenvolvimento de industrialização exportadora de manufaturas. Esse mecanismo de auto anulação garantia o predomínio dos mecanismos de mercado para o sucesso da economia coreana.

Portanto, afirma o estudo, não foi uma política de intervenção do Estado de caráter desenvolvimentista por meio da política de substituição de importações que gerou o elevado crescimento da Coreia do Sul, mas sim uma política orientada segundo os mecanismos do livre mercado em que o Estado exerceu apenas um papel suplementar no funcionamento do mercado.

No estudo publicado em 1993, o Banco Mundial mantém a mesma linha de interpretação sobre o sucesso dos países do Leste Asiático, inclusive sobre a Coreia do Sul. Nesse estudo, o Banco Mundial reconhece o papel do Estado no sucesso da economia coreana, mas afirma que esse papel foi limitado e no sentido de fortalecer o perfeito funcionamento dos mecanismos do livre mercado. 
O Banco Mundial (1993) afirma que houve um sistema de políticas intervencionistas que utilizou vários canais no sentido de promover o desenvolvimento. As diferentes formas de intervenções foram as várias maneiras de crédito direcionado para indústrias selecionadas, proteção aos substitutos de importação, subsídios domésticos para indústrias em declínio, o estabelecimento e apoio financeiro do governo por meio dos bancos públicos, os investimentos públicos em pesquisa aplicada, entre outros. O diferencial dessas medidas nos países do Leste Asiático, como o caso da Coreia do Sul, reside no fato de que não provocaram uma distorção no sistema de preços do mercado, pelo contrário, ocasionaram alta taxa de acumulação, alocação eficiente dos recursos e tendo como consequência óbvia o crescimento da produtividade. Na verdade, afirma o estudo do Banco Mundial (1993), as políticas associadas ao market-friendly são as responsáveis pelo sucesso dos países do Leste Asiático, já que as economias que seguiram as orientações do mercado têm conseguido criar um ambiente macroeconômico estável, com alta participação no comércio internacional e elevado crescimento econômico, substancial investimento em pessoas e o estímulo ao ambiente competitivo entre as empresas.

Em linhas gerais, a principal identidade entre os estudos de interpretação neoclássica sobre a Coreia do Sul é a defesa da irrelevância do papel do Estado em todo o processo e o respeito a estrutura de preços relativos ditada pelo mercado. Para os autores apresentados aqui, a política de substituição de importações causa uma distorção dos preços relativos na proporção em que as medidas de política econômica protegem o mercado interno em detrimento da competição externa, gerando assim um viés antiexportação. Por outro lado, quando um país adota a estratégia de crescimento liderado pelas exportações, a política de incentivos é implementada de forma equitativa beneficiando as exportações e as importações, expondo a economia nacional à concorrência externa e, consequentemente, promovendo uma intensa concorrência que inibe os desequilíbrios no mercado e faz prevalecer a alta produtividade.

A segunda corrente teórica que debate o desenvolvimento econômico da Coreia do Sul é a heterodoxa endogenista, a qual coloca o Estado como elemento central e o principal ator desse processo. Os principais representantes são Alice Amsden e Ha-Joon Chang. 
Amsden (1989) afirma que a interpretação de cunho liberal sobre a Coreia do Sul não passa de uma nota de rodapé que distorce por completo e apresenta ideias errôneas sobre o real entendimento do processo de desenvolvimento da economia coreana. Para Amsden (1989), assim como outros países de industrialização tardia, o caso da Coreia deixa nítido que não foram os mecanismos de mercado responsáveis pelo avanço da sua economia, mas sim uma forma peculiar de atuação do Estado. Segundo a autora, a compreensão de uma economia de industrialização tardia exige a percepção de que o Estado intervencionista é um agente fundamental como promotor do desenvolvimento econômico na medida em que, deliberadamente, distorce os preços relativos com o objetivo de estimular o crescimento econômico e estimular grupos empresariais a diversificar em todos os setores da economia com expansão da produtividade para tornar o país competitivo. Nesse sentido, a autora afirma que é necessário entender três dimensões básicas da condução da política econômica nos países de industrialização tardia, quais sejam: $1^{\circ}$ ) a política para promover a diversificação e as decisões empresariais para a entrada em novas indústrias; $2^{\circ}$ ) a política macroeconômica para manter a atividade econômica; e $3^{\circ}$ ) o crescimento em si mesmo, isto é, a relação entre o crescimento econômico e a expansão da produtividade.

Na primeira dimensão Amsden (1989) afirma que a entrada das empresas coreanas em novos setores da manufatura foi instigada pelo Estado. Foi por meio das políticas de incentivos e subsídios inseridas nos Planos Quinquenais ${ }^{1}$ que teve início o processo de substituição de importações - na indústria de cimento, fertilizantes, refino de petróleo e fibras sintéticas -, avançando para os períodos 1970 e 1980, quando as intervenções do governo foram essenciais para o Big Push na estrutura industrial coreana, atingindo a indústria automobilística, pesada e química nos anos 1970. Nos anos 1980 a indústria eletroeletrônica e a produção de semicondutores e computadores tiveram uma maior ênfase. $\mathrm{O}$ fato é que o avanço do parque industrial coreano, com a entrada em novos setores e ampla diversificação, só foi logrado por meio da forte intervenção do

(1) Na seção 3 do artigo tem dois quadros com uma síntese dos planos quinquenais, seus objetivos, resultados e as principais políticas adotadas pelo governo coreano. 
governo através de uma combinação de políticas de promoção para a diversificação aliada aos subsídios, incentivos e protecionismo que distorcem os preços do mercado. Houve uma forte cooperação entre Estado e setor privado que fica evidenciada na relação entre o governo coreano e as Chaebols.

$\mathrm{Na}$ segunda dimensão a autora afirma que a política macroeconômica foi marcada pela busca constante de promover o crescimento, mesmo nos cenários externos desfavoráveis como na crise do primeiro e segundo choques do petróleo, assim como na crise dos anos 1980. Ao contrário dos países da América Latina e dos que defendem os argumentos liberais, nos momentos de cenários externos desfavoráveis o governo coreano adotou uma política macroeconômica expansionista implementando medidas tais como: o estímulo às exportações por meio da desvalorização cambial e incentivos fiscais; expansão do crédito; controle da taxa de juros para estimular os investimentos; manutenção da política de subsídios para a indústria pesada; política de forte endividamento externo e o resgate de empresas em dificuldades. Esse conjunto de medidas criou um ambiente propício para a forte expansão econômica associado ao crescimento significativo das exportações de manufaturas, particularmente da indústria pesada.

A terceira dimensão apresentada pela autora é a dinâmica do crescimento da produtividade nas industrializações tardias. Após fazer críticas aos modelos convencionais do crescimento, afirmando que eles são falhos e inapropriados para analisarem as economias de industrialização tardias por não considerarem os fatores que geram alta produtividade, Amsden (1989) afirma que nas economias de industrialização tardia a taxa de crescimento pode influenciar no nível de crescimento da produtividade, assim como o crescimento da produtividade pode corroborar para o crescimento econômico. Com isso, a autora mostra que os fatores fundamentais para a expansão da produtividade podem ser obtidos por meio de três mecanismos, quais sejam: 1) através da importação de tecnologia estrangeira; 2) a operação de tecnologia estrangeira em uma escala crescente vai contribuir para minimizar os custos de produção; 3 ) e $\mathrm{o}$ processo de aprendizagem (learning-by-doing) no uso e emprego 
eficiente de tecnologia estrangeira. Segundo a autora, esses três fatores apresentados como elementos fundamentais para o crescimento da produtividade e do crescimento econômico, apontam para o papel chave que tiveram as políticas de intervenção do governo no sentido de manter o ritmo de crescimento da economia em níveis elevados e a transformação estrutural do país.

O segundo autor da corrente heterodoxa endogenista é Chang. Para Chang (1994), os argumentos dos defensores do mainstream economics, ao desqualificar e negar o papel do Estado no sucesso da economia coreana, tem bases teóricas e empíricas frágeis e irreais. Do ponto de vista teórico, quando os estudos neoclássicos defendem a existência de um sistema de incentivos neutro na Coreia não é nítido em seus argumentos como o sistema de incentivos para as exportações (em um modelo orientado para fora) pode anular as medidas protecionistas em relação às importações (em um modelo de substituição de importações), pois se as estruturas de preços sob os dois regimes são diferentes, não se pode afirmar que a estrutura de incentivos sob o modelo de orientação para fora é neutro, já que o que importa na determinação da atratividade relativa das exportações e produção para o mercado doméstico é a estrutura de preços relativos e não a média de incentivos, como acreditam os neoclássicos.

Do ponto de vista empírico, Chang (1994) afirma que quando se analisa os indicadores da economia coreana, ao contrário do que defendem os neoclássicos de que houve livre comércio na Coreia, há evidências do controle do comércio externo, principalmente quando se leva em consideração que os exportadores não tinham acesso livre a importações de insumos (matérias-primas e máquinas) a preços de mercado mundiais. Predominava um sistema de controle das importações, a exemplo do controle da importação de máquinas que foi rigorosamente controlado de acordo com os interesses de promover a indústria de máquinas nacional, visto como essencial para a construção de uma economia com um parque industrial completo e bem integrado. Além do mais, a política de crédito sempre apresentava recusa aos importadores de máquinas quando havia a oferta desses bens no mercado interno. Por outro lado, afirma o autor, havia amplo crédito subsidiado para os compradores de máquinas e equipamentos de origem doméstica. 
Chang (1994) argumenta que as evidências teóricas e empíricas do dirigismo estatal no processo de desenvolvimento coreano ficam explícito na análise dos vários Planos Quinquenais e na sua execução. Por exemplo, do ponto de vista macroeconômico, as medidas foram no sentido de alavancar o investimento como variável chave para estimular o crescimento econômico e a transformação estrutural do país. A estratégia coreana era manter um alto nível de investimento através da "gestão de investimentos" para dar o upgrading na estrutura industrial. Mas apenas estimular os investimentos não seria suficiente para superar as deficiências no parque industrial e ao mesmo tempo avançar com elevado nível de crescimento de competitividade das empresas. Para isso, o governo coreano implementou uma política industrial de caráter seletiva, escolhendo setores prioritários, dando apoio financeiro, técnico e administrativo às empresas selecionadas - os grandes chaebols.

A terceira linha de interpretação sobre o desenvolvimento econômico coreano defende que o cenário externo se mostrou sempre favorável ao país, criando assim as condições necessárias para que a Coreia sempre encontrasse alternativas viáveis para a continuidade do caminho do crescimento elevado e da profunda transformação estrutural. Os principais autores selecionados nesse artigo foram Medeiros (1997) e Cho (2001).

Para Medeiros (1997), o processo de desenvolvimento econômico coreano deve ser entendido quando se observa a predominância de um contexto externo completamente favorável aos países do Leste Asiático, entre eles a Coreia do Sul. Os principais fatores que comprovam tal afirmação são: 1) como resultado da estratégia dos EUA do pós-guerra de ampliação de seus interesses econômicos e políticos na Ásia, houve uma constante ampliação do superávit comercial dos países da região asiática com os países da OCDE exportando manufaturados; 2) expansão dos investimentos dos EUA e do Japão na região, com os EUA colocando-se como mercado das exportações dos manufaturados dos países asiáticos e o Japão como um dos principais países responsáveis pela transferência de tecnologia via importação de bens de capital; 3) e expansão do financiamento externo. Essas três variáveis explicam o diferencial de 
performance dos países da Ásia, particularmente a Coreia do Sul, quando comparado com os países da América Latina, como é o caso do Brasil, principalmente quando consideramos os anos 1980.

Por exemplo, Medeiros (1997) argumenta que a contração do crédito no mercado internacional nos anos 1980 alterou de forma substancial a inserção externa dos países da periferia. Mas enquanto os países asiáticos foram beneficiados pelas suas relações com o Japão e com os EUA, os países da América Latina sofreram com a escassez de financiamento externo, instabilidade macroeconômica e desinvestimento. Esse cenário gerou um processo de estagnação na trajetória de desenvolvimento dos países da América Latina, enquanto os países da Ásia, especialmente a Coreia do Sul, mantiveram sua sequência de crescimento e transformação estrutural. Para o autor, os EUA e o Japão serviram de locomotiva para a Coreia do Sul na medida em que os recursos financeiros desses países evitaram um colapso nas contas externas coreanas, pois mesmo com a Coreia apresentando uma grande necessidade de realizar transferências financeiras ao exterior, isso foi feito em uma menor proporção e sem restringir sua capacidade de crescimento, já que a relação com os EUA e o Japão fez com que os choques de juros, a deterioração nos termos de troca nos anos 1980 e a queda da demanda mundial não atingissem a Coreia do Sul como atingiram, por exemplo, a economia brasileira.

Outro autor que segue essa mesma linha de interpretação sobre o desenvolvimento coreano é Cho (2001). O autor considera que a maioria dos estudos sobre o desenvolvimento da Coreia do Sul não leva em consideração o aspecto principal e determinante: o cenário externo favorável. Para o autor, é inegável que o ambiente econômico internacional em torno da Coreia teve um impacto significativo não apenas nos negócios de curto prazo, mas em todas as fases de desenvolvimento do país, por exemplo: as constantes ajudas financeiras e ermpréstimos dos EUA; o fluxo de recursos direcionados do Japão para a Coreia como reparação e empréstimos preferenciais; a importância da participação da Coreia na Guerra do Vietnã que lhe rendeu benefícios, já que a Coreia passou a ser considerada uma região estratégica para os EUA durante a 
Guerra Fria; a expansão do Euromercado após o primeiro choque do petróleo porque ampliou os recursos externos para a Coreia; e a retomada de relações políticas e comerciais com o Japão que foi essencial nos anos 1980 para a Coreia do Sul. Em seu trabalho, Cho (2001) deixa nítido que todos os acontecimentos na economia internacional favoráveis à Coreia do Sul foram condições sino qua non para que o país lograsse o estágio de desenvolvimento econômico, pois sem esse cenário externo favorável a Coreia seria apenas mais um país em desenvolvimento com vários problemas estruturais sem conseguir superá-los.

Para Cho (2001), vários indicadores analisados ao longo da história coreana apontam e confirmam que o cenário externo foi a essência do desenvolvimento econômico coreano. Por exemplo, apesar do país ter a menor taxa de poupança entre os chamados quatro tigres que embarcaram na trajetória do desenvolvimento econômico nos 1950 e 1960, a Coreia registrou uma das maiores taxas de crescimento e de investimento. Este fato só foi possível por causa da capacidade do país de aquisição de capital estrangeiro, o qual deu condições para a continuidade de um crescimento e transformação estrutural tendo como fundamento o endividamento externo. De acordo com o autor, poucos países em desenvolvimento tiveram condições de transferir a dívida adquirida do exterior para o investimento industrial, principalmente quando levamos em consideração que o mercado de capitais não era tão desenvolvido ainda. Sob a estrutura da Guerra Fria, devido a sua relação especial com os EUA e o Japão, a Coreia ficou em uma posição muito mais vantajosa para receber capital estrangeiro desses países. Além do mais, embora a Guerra do Vietnã tenha causado o sacrifício de muitos jovens soldados da Coreia, ela foi fundamental como uma ponte para que a economia coreana entrasse em setores como a construção civil no exterior, transporte e indústria, viabilizado pelo serviço de encomendas especiais que foi atribuído ao país pelos EUA, além do Brown Memorandum - o qual deu prioridade a Coreia nas compras governamentais dos EUA na região asiática.

A apresentação dessas correntes teóricas deve estar associada a alguns cuidados relevantes para evitar um reducionismo das ideias dos autores discutidos nesse artigo: 1) ao afirmar que a corrente heterodoxa 
endogenista defende a hipótese de que o Estado foi o principal ator do processo de desenvolvimento da Coreia, isso não significa que os autores desconsideram uma avaliação do cenário externo como elemento importante. Ambos os autores discutem essa dimensão e apontam para vários fatos geopolíticos que foram cruciais na história da Coreia. Entretanto, mesmo reconhecendo a essencialidade da dimensão externa favorável, para eles a centralidade do papel do Estado é o elemento primordial para a compreensão do chamado sucesso da trajetória de desenvolvimento da Coreia; 2) em relação a apresentação das ideias dos defensores da hipótese de que o cenário externo sempre foi favorável à Coreia, os autores estão preocupados em discutir o cenário geopolítico em vários momentos históricos e sua relação com a trajetória de desenvolvimento da Coreia, mas eles não ignoram os méritos da construção e implementação das políticas internas adotadas pelo governo. $\mathrm{Na}$ verdade, para esses autores, os fatores internos exercem um papel secundário na explicação do sucesso do país, enquanto o cenário externo é a variável vital para evidenciar os motivos do sucesso da economia coreana.

\subsection{A alternativa de interpretação a partir das ideias da Escola de Campinas}

A partir da apresentação dessas interpretações sobre a Coreia, considera-se importante neste artigo a contribuição da corrente neoclássica para o debate sobre o processo de desenvolvimento econômico dos países de industrialização tardia ao levantar questionamentos sobre as diferenças entre os modelos outward-looking - expor-led e inward-looking - importsubstitution. Entretanto, este trabalho se contrapõe a interpretação de cunho neoclássico por identificar nessa interpretação o seu caráter ahistórico e não haver correspondência com o que de fato aconteceu na Coreia do Sul ao longo do seu processo de desenvolvimento. Quando se levam em consideração as principais hipóteses e ideias das interpretações neoclássicas nos estudos comparativos nos processo de desenvolvimento econômico, particularmente considerando o debate acerca das teorias do comércio internacional, os principais axiomas são: a) a não existência de barreiras ao comércio; b) modelos baseados em uma estrutura de mercado 
de concorrência perfeita nos mercados de bens e de fatores de produção; c) as funções de produção são similares entre as nações envolvidas no comércio internacional, diferentes entre os setores produtivos e apresentam rendimentos constantes de escala; d) há livre mobilidade dos fatores de produção entre os setores produtivos, mas entre os países não existe livre mobilidade, com os preços totalmente flexíveis; e) os produtos e os fatores são homogêneos em ambos os países.

O que pode ser observado é que mantidas as hipóteses fundamentais da ortodoxia clássica e neoclássica, os padrões de especialização relativa de cada país conformam-se através de ajustamentos em preços e quantidades, sem alterar o nível setorial ou global de utilização de recursos, ou melhor, sem alterar o nível da renda. Isso significa dizer que o comércio internacional interfere na alocação intersetorial de recursos, quantidades e preços, sem afetar o nível da atividade econômica e acarretando ganhos de comércio para todos os participantes, ou seja, o potencial de geração de renda (poder de compra) é o mesmo em todos os setores. Portanto, a equalização dos preços dos fatores seria alcançada com a divisão do trabalho e a troca internacional, direcionada pelo princípio da dotação de fatores, provocando a redução das diferenças e convergência dos preços existentes entre as nações no emprego dos fatores de produção.

Vários estudos refutaram empiricamente a assertiva de que o perfil da estrutura produtiva e a especialização comercial não contam substancialmente para o desempenho econômico relativo, exigindo que questionemos as suposições teóricas do liberalismo econômico. Se quisermos entender o modo como as diferentes formas de especialização produtiva e inserção comercial influenciam o desempenho econômico relativo dos países, é necessário contrapor a visão liberal à constatação de que o comércio não afeta apenas a alocação de recursos, mas também os diferenciais internacionais de crescimento da renda. Além do mais, explicar porque a diversidade de especializações e/ou de competitividade nas mesmas especializações é importante para elucidar diferenciais de crescimento e porque as políticas dos Estados nacionais são relevantes para definir a distribuição dos ganhos e perdas envolvidas nas interações econômicas internacionais. 
Além deste trabalho se contrapor aos estudos de cunho neoclássicos pelas razões expostas, não se acredita que o Estado tenha sido o único e principal ator no processo de condução da política econômica e seria isso que diferenciaria a Coreia de outros países de industrialização tardia. Ao mesmo tempo, não se considera que o cenário externo favorável a Coreia do Sul tenha sido o principal determinante para que o país tenha logrado o tão chamado "sucesso".

A interpretação adotada neste trabalho é o de se considerar tanto o cenário externo, como também as condições internas as quais estão associadas à condução da política econômica do país. Adota-se uma postura de interpretação a qual defende a hipótese de que o elevado crescimento econômico e a profunda transformação estrutural apresentada pela Coreia foram resultantes de um cenário externo favorável ao país em diferentes momentos históricos, aliado a uma condução da política econômica que permitiu ao país lograr seus objetivos consubstanciados nos planos quinquenais. O que leva este artigo a adotar essa linha de interpretação e defender essa hipótese é a de que o cenário externo favorável gerou condições para que a Coreia construísse um conjunto de medidas de política interna coesa que se diferenciou de outras economias de industrialização tardia nas questões como: 1) a estrutura de propriedade do capital; 2) organização empresarial; 3) a centralização do capital; e 4) o processo de absorção e desenvolvimento tecnológico. Consideram-se essas relações entre cenário externo e interno, mas partindo do princípio de que a estrutura socioeconômica coreana e a condução da política econômica interna nas medidas citadas logo acima são determinantes em primeira instância, e em última instância as condições externas favoráveis a Coreia.

Nesse sentido, segue-se a linha de pensamento do Instituto de Economia da Unicamp com a ideia de entender o processo de industrialização dos países de caráter tardio considerando suas peculiaridades interna e externa em cada momento em seu contexto histórico, com os fatores internos sendo colocado na primeira instância para compreender o processo de industrialização das economias tardias e os fatores externos em última instância. 
A Escola de Campinas desdobrou-se a partir da concepção estruturalista latino-americana, segundo a qual não há padrões universais de desenvolvimento, mas modos de desenvolvimento historicamente particulares que se relacionam internacionalmente. Como a Cepal, a Escola de Campinas rejeitava modelos teóricos liberais que supunham uma complementaridade harmônica entre economias de graus diferenciados de desenvolvimento e/ou a existência de um mesmo roteiro universal de desenvolvimento econômico. Mas, concomitantemente, conferia-se mais atenção aos determinantes internos dos modelos de desenvolvimento. Parte-se do princípio de que o movimento do capitalismo mundial produziria condicionantes estruturais para os modelos e estratégias de desenvolvimento de países periféricos, mas não os determinaria. Os condicionantes externos poderiam ser mais ou menos restritivos em última instância, mas a autonomia relativa dos determinantes internos, em primeira instância, é o que permitiria comparar as diferenças entre as próprias economias periféricas, explicando as formas de reação aos impulsos, restrições e, eventualmente, janelas de oportunidade do cenário internacional. Os trabalhos pioneiros da Escola de Campinas na interpretação do desenvolvimento capitalista brasileiro foram os de Maria da Conceição Tavares (1974), João Manuel Cardoso de Mello (1975) e Oliveira (2002). Em todos, não se rejeitava a ênfase cepalina nas assimetrias internacionais, mas de diferentes maneiras se conferia maior centralidade a aspectos internos da acumulação de capital no Brasil.

No caso do capitalismo tardio de Mello (1975), por exemplo, o desenvolvimento capitalista se fez na época do capitalismo monopolista e em países de passado colonial, em um contexto radicalmente diferente das metrópoles imperiais que transitaram antes para o capitalismo industrial a partir de um passado feudal. No Brasil, o processo de industrialização teve início em meio a uma economia capitalista agroexportadora, em um momento em que a estrutura das indústrias dos países industrializados já se transformava em oligopólios relativamente fechados a entrantes potenciais - graças à constituição e reprodução de capacitações financeiras e tecnológicas assimétricas, cumulativas e apropriáveis pelas grandes firmas em sua localização original e crescentemente fora dela. Dessa perspectiva, 
os obstáculos colocados à liderança do setor privado nacional implicavam um protagonismo maior do Estado e da filial estrangeira na superação da industrialização restringida. A determinação da divisão de tarefas e da dimensão exata dos papéis de Estado e filiais em cada caso nacional de desenvolvimento capitalista tardio, porém, não podia ser feita no nível de abstração da análise econômica apresentada, devendo ser objeto de pesquisa histórica particular.

Segundo Oliveira (2002), um dos principais expoentes do referencial teórico do Instituto de Economica da Unicamp, a interpretação da gênese do capitalismo em diferentes nacões, deve levar em consideração as circunstâncias históricas do seu desenvolvimento em cada país e através das mediações históricas, identificando as particularidades de cada nação. Dentro desse princípio, considera-se que a história não se reproduz como se houvesse um modelo, de modo que o entendimento do desenvolvimento econômico de cada país exige uma volta para o processo concreto em que se desenvolveu o país, processo este que aparece determinado por condições históricas tanto locais como do desenvolvimento da economia capitalista mundial. Considerar as mediações históricas para compreender as particularidades do processo de desenvolvimento capitalista de cada nação exige considerar o estágio de desenvolvimento do capitalismo em sua dimensão mundial e, simultaneamente, levar em consideração todo o processo de transformação desse país analisando as mudanças no esquema departamental de reprodução do capital social, a estrutura social que precedeu a fase capitalista e as lutas sócio-políticas que encaminharam a transição capitalista. Assim, a evolução de um país é duplamente determinada em primeira instância pela estrutura social deste país, e em última instância, pela etapa vivida pelo capitalismo mundial, como Oliveira (2002) afirma:

(...) a evolução do capitalismo em diferentes nações não constitui mera reprodução dos processos ocorridos nas nações avançadas. A evolução dos diversos capitalismos nacionais não é mero reflexo da economia mundial, ou seja, que as economias nacionais guardam certas especificidades. Por outro lado, a gênese do capitalismo em cada nação é determinada pelas circunstâncias históricas nas quais 
este processo está imerso. Vale dizer, a formação do capitalismo em cada nação é determinada, em primeira instância, pelo passado, pela estrutura econômica e social que precede o capitalismo; mas esse processo é também determinado, em última instância, pela etapa vivida pelo capitalismo em âmbito mundial (Oliveira, 2002, p. 96).

\section{Uma síntese da evolução histórica da Coreia do Sul: o cenário externo favorável}

A análise do cenário externo é fundamental para o entendimento da evolução da economia coreana e diferenciá-la de outros países de industrialização tardia, como é o caso do Brasil. Em diferentes momentos históricos, o cenário externo foi extremamente favorável para a Coreia do Sul. No primeiro momento, durante a colonização japonesa, houve alguns benefícios para a Coreia, embora fosse uma colônia e predominasse a relação entre centro e periferia tendo como consequências, por exemplo, o empobrecimento rural e o aprofundamento da dependência política. No início da Segunda Guerra Mundial, o Japão incentivou as Zaibatsus a transferir para a Coreia alguns setores industriais com o intuito de que essas empresas produzissem produtos e depois transferisse para a metrópole, resultando assim no aumento da participação da indústria pesada na indústria manufatureira na Coreia do Sul, assim como criando uma infraestrutura no país e dando início à formação de mão-de-obra qualificada (Cumings, 1987).

É importante considerar que além da formação de uma infraestrutura e mão-de-obra qualificada herdado pela Coreia através do processo de colonização japonesa, há também uma influência do Japão na relação entre Estado e setor privado. Se no Japão a aliança entre governo e Zaibatsu era essencial para que o país pudesse dar continuidade ao seu desenvolvimento, esse modelo foi transferido para a Coreia em uma aliança estabelecida entre o Estado e as grandes empresas familiares coreanas, os Chaebols. O Japão corroborou com o fortalecimento do nacionalismo na Coreia, característica esta fundamental para compreender a presença de um Estado forte e o processo de implementação da política de desenvolvimento associada com a política de captação de recursos externos (Cumings, 1987; Amsden, 1989). 
Com o fim da Segunda Guerra Mundial, a destruição do Japão e o fim do domínio japonês sobre a Coreia, o novo cenário geopolítico internacional vai ser fundamental para a Coreia do Sul. Com o processo de reconstrução do Japão, os EUA estabelecem um período curto (1945-1948) de ocupação na Coreia do Sul ao visualizar nesse país um aliado estratégico na nova divisão internacional político com o pós-guerra. A Coreia é vista como um país essencial como ofertante de bens - por exemplo como grãos - e ao mesmo tempo como mercado de absorção dos produtos japoneses. A visão de que a Coreia do Sul seria um país importante no reordenamento do quadro político internacional, fazia do país um aliado estratégico para os EUA mais do ponto de vista político do que econômico, pois a Coreia teria relevância para os EUA tentarem conter a expansão da influência dos soviéticos na região.

De qualquer forma, essa nova visão dos EUA em relação a Coreia nesse momento foi significativa para o país em vários sentidos. Por exemplo, foram os EUA responsáveis pela reforma agrária e pelo estímulo da formação de mão-de-obra qualificada no país. A reforma agrária contribuiu para a distribuição de terras e reduziu a concentração fundiária, além de enfraquecer toda uma classe de aristocratas resultante do período de colonização japonesa. Esse processo foi relevante para fortalecer a emersão de uma classe empresarial no país. A outra contribuição com a ocupação americana foi o processo de alfabetização na nação. Os EUA implantaram um amplo sistema de alfabetização e formação educacional na Coreia, elevando notavelmente o índice de alfabetização e, consequentemente, formação de mão-de-obra qualificada (Hugh Jo, 2011; Cho, 2001).

Com o fim da ocupação americana e o estabelecimento do primeiro governo presidencial na Coreia em 1948 - o presidente era Syngman Rhee -, já em 1950 o país enfrentou a Guerra da Coreia. Essa guerra teve resultados desastrosos para o país, tendo em vista que toda infraestrutura criada foi profundamente atingida e isso acabou impactando também na formação de mão-de-obra qualificada, pois a infraestrutura que empregava essa mão-de-obra qualificada não mais existia ou estava muito danificada, exigindo uma realocação desses trabalhadores para setores que 
não correspondiam a sua qualificação. Ao mesmo tempo em que a Guerra teve resultados catastróficos para a Coreia do Sul, pode-se argumentar que teve seu lado positivo. Essa afirmação se sustenta ao observarmos que a Coreia do Norte se tornou aliada dos países considerados comunistas, realçando a posição estratégia da Coreia do Sul para os EUA. Essa aliança política dos EUA com a Coreia do Sul vai gerar um amplo leque de benefícios econômicos para o país, principalmente no que se refere à ajuda financeira externa (Cumings, 1987; Cho, 2001).

Ainda no começo dos anos 1950 tem início a Guerra do Vietnã (1955-1975), a qual estreitou os laços entre a Coreia do Sul e os EUA, fortalecendo assim as remessas de recursos dos EUA para a Coreia. Apesar das grandes baixas de soldados militares ao enviar suas tropas para a guerra, a contrapartida foi um vultoso aporte de ajuda externa para o fortalecimento da área militar, permitindo ao governo coreano economizar recursos com gastos militares e realocar recursos para outras áreas estratégicas da economia como na construção civil, transporte, infraestrutura e a indústria.

No debate acerca da contribuição financeira dos EUA para a Coreia, muitos estudos apontam para o fato de que isso diminuiu no início dos anos 1960, o que na verdade já vinha acontecendo há um tempo antes, já que nos anos 1950 o caráter da relação entre EUA e Coreia transita de ajuda financeira para empréstimo externo, inclusive com participação do setor privado. Durante os anos 1950, essa transição de ajuda financeira para empréstimos coincide com uma redução dos recursos americanos para a Coreia e isso parecia indicar que a relação com os EUA iria comprometer a existência de um cenário externo favorável para a Coreia do Sul. Todavia, emerge nesse período um novo cenário que mais uma vez irá propiciar novos elementos para a continuidade de um cenário benéfico para o país. Esse novo cenário é a retomada das relações diplomáticas entre Japão e Coreia do Sul, sacramentada pelo chamado Tratado de Normatização.

A retomada das relações diplomáticas com o Japão não se limitará à entrada de recursos, mas também a retomada de relações comerciais com o Japão o qual será um grande mercado consumidor dos bens coreanos, 
além das parcerias no processo de aprendizado tecnológico. Para Cho (2001), a dimensão da importância do Japão para a Coreia durante o período fica em evidência quando se analisa a participação dos recursos japoneses no valor total das exportações, participação esta que ficou em 23\% entre 1967-1971. Portanto, fica claro que se os recursos externos dos EUA foram importantes para a Coreia nos anos 1940 e 1950, enquanto os recursos japoneses foram relevantes nos anos 1960 e 1970.

Nos anos 1970, uma série de acontecimentos criaram um cenário externo desfavorável principalmente para os países de industrialização tardia. Isso tem início com o Primeiro Choque do Petróleo em 1973 e seu aprofundamento com o Segundo Choque do Petróleo em 1979, além da política de elevação das taxas de juros dos EUA. Esse cenário adverso coincide com a necessidade de maiores recursos da Coreia para o financiamento do Terceiro Plano Quinquenal em 1973, que tinha como objetivo central o fomento da industrialização química e pesada, tornando mais imperativa a necessidade de recursos externos para complementar o vultoso volume de capital para os objetivos dos planos de desenvolvimento. Entretanto, além do cenário externo adverso, a Coreia do Sul irá ter que enfrentar agora uma situação delicada tendo em vista que os seus principais parceiros, como EUA e Banco Mundial, colocaram-se contra a execução desse plano considerando-o inviável para o país (Medeiros, 1997; CHO, 2001).

Nesse sentido, além a retomada das relações políticas e comerciais com o Japão, o surgimento do Euromercado pode ser considerado providencial para a Coreia do Sul. Enquanto os EUA tinham adotado uma política de restrição ao crédito durante o período, a emergência do Euromercado facilitou a movimentação financeira no mercado interbancário internacional, corroborando para a expansão da liquidez no sistema financeiro internacional. A expansão do Euromercado beneficiou muito a Coreia do Sul, ainda mais no momento em que o país implementava a promoção das indústrias pesada e química. Segundo Cho (2011), considerando os países em desenvolvimento, a Coreia do Sul foi o país que mais recebeu recursos oriundos do Euromercado, seguidos do México e do Brasil. 
Com o Segundo Choque do Preço do Barril do Petróleo em 1979 e a elevação das taxas de juros dos EUA, predominou no cenário internacional no final dos anos 1970 e início dos anos 1980 uma contração da liquidez no sistema financeiro, ameaçando todos os países dependentes de recursos externos para financiar seu desenvolvimento. Enquanto a América Latina sofreu com a contração de entrada de recursos externos nos anos 1980, a Coreia do Sul teve uma situação privilegiada, principalmente em decorrência da sua relação com o Japão, tanto na concessão de crédito como também no seu comércio exterior e no processo de absorção de tecnologia, propiciando assim um ambiente externo oportuno para que a Coreia pudesse manter a política de desenvolvimento do seu parque industrial atrelado a taxas de crescimento elevadas.

Se nos anos 1970 a trajetória da economia coreana gerou um amplo debate em torno das origens e motivos do sucesso da Coreia do Sul, nos anos 1980 esse debate se fomenta, sobretudo porque a Coreia do Sul apresentou uma performance macroeconômica e de comércio exterior que o diferenciou de outros países em desenvolvimento. Um dos principais argumentos para a continuidade da elevada performance da Coreia foi suas relações econômicas e políticas com os Estados Unidos e Japão, que facilitaram o processo de enfretamento da crise com acesso ao financiamento externo - por exemplo, situação esta que a economia brasileira não encontrou -, dando assim condições para a continuidade do desenvolvimento econômico coreano. De fato, os EUA e mais ainda o Japão foram essenciais na concessão de crédito, no comércio exterior como mercado de destino das exportações e origem das importações, assim como no processo de absorção de tecnologia.

Como pode ser visto no Gráfico 1, no início dos anos 1970 a participação dos Estados Unidos como principal destino das exportações da Coreia era de $46,8 \%$ e a participação do Japão era de $28,1 \%$. Somando as participações desses dois países como destinos das exportações da Coreia o percentual era de 74,9\%. A participação dos Estados Unidos como origem das importações da Coreia em 1970 era de $29,5 \%$ e a do Japão de 40,8\%, totalizando um percentual de 70,3\%, deixando em evidência a relevância que os EUA e o Japão tiveram para a Coreia do Sul. 
De acordo com os indicadores do Gráfico 1, ao longo dos anos 1970 houve uma pequena queda da participação desses países como destino das exportações e origem das importações, mas ainda assim o Japão e os Estados Unidos continuaram sendo os principais parceiros comerciais da Coreia.

No final dos anos 1980, os percentuais de participação dos Estados Unidos e do Japão como destino das exportações e origem das importações voltam a se elevar e ficam em patamares similares aos do início dos anos 1970, apontando para o fato de que os EUA e o Japão continuaram sendo essenciais não apenas como destino das exportações e como credores internacionais da Coreia do Sul - o que possibilitou as condições favoráveis para o país manter as elevadas taxas de investimentos -, mas também continuaram sendo primordiais como fontes de transferência de tecnologia para o desenvolvimento da indústria mais intensiva em tecnologia. Segundo Kim (2005a), o Japão permaneceu tendo maior participação como fonte de tecnologia para a Coreia - basta perceber que a participação do Japão como origem das importações é maior do que dos EUA ao longo de toda a década de 1980 -, enquanto os EUA foi o maior mercado de destino das exportações coreanas.

\section{Gráfico 1}

Destino das exportações e origem das importações da Coreia do Sul - Participação

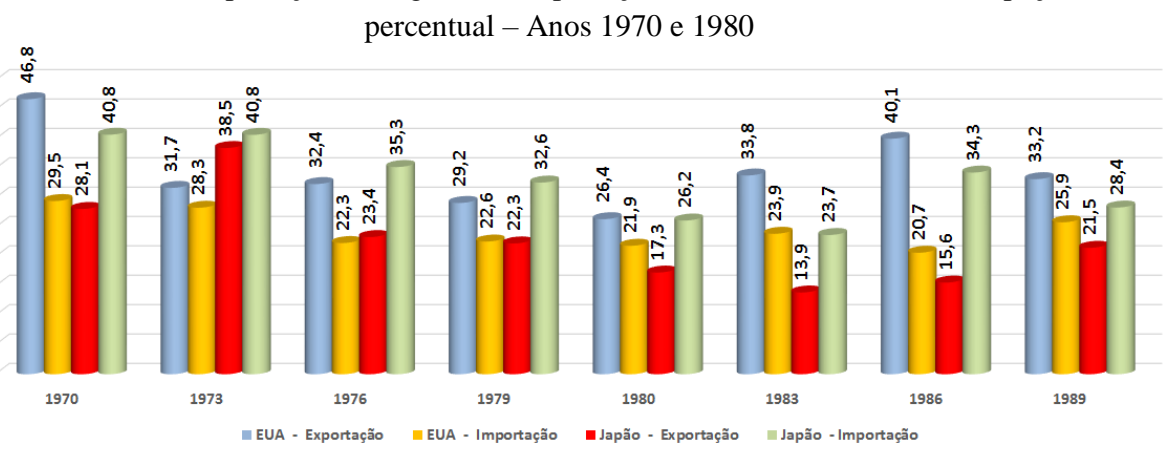

Fonte: United Nations Commodity Trade Statistics Database (Comtrade).

Um ponto importante para a Coreia do Sul nos anos 1980 foi o Acordo de Plaza. O Acordo de Plaza realizado pelo G5 em 1985 forçou 
uma pronunciada valorização do iene frente ao dólar - em um ano o dólar passou de 250 para 155 ienes - e inaugurou uma ampla ofensiva comercial dos EUA, visando reverter seu déficit estrutural na balança comercial com o Japão. Na verdade, o Acordo de Plaza foi uma negociação entre os governos do G-5 (EUA, Japão, Alemanha, Reino Unido e França) para estabelecer a coordenação multilateral, a fim de reduzir as crescentes pressões protecionistas que poderiam levar a uma retaliação mutuamente destrutiva, com graves danos para a economia mundial (Medeiros, 1997).

O Acordo de Plaza, a valorização do iene, a estratégia de investimentos do Japão e o crescimento da economia americana foram acontecimentos importantes para a construção de um ambiente externo benéfico à Coreia do Sul. Entretanto, não se pode desconsiderar que esses acontecimentos citados estão associados à estratégia da política cambial praticada pela Coreia do Sul, ou seja, mesmo com fatores externos sendo favoráveis ao país, a estratégia da política interna em relação ao câmbio foi fundamental para o bom aproveitamento do cenário externo benéfico. Com isso, na primeira metade dos anos 1980, o país desvalorizou sua moeda em relação ao dólar e seguiu a mesma estratégia do iene. Na segunda metade da década, a Coreia seguiu o movimento do dólar ao desvalorizar sua moeda em relação ao iene.

Afirmar que o cenário externo foi o fator determinante, em primeira instância, com os fatores internos sendo colocados em última instância e considerados apenas como elementos secundários ou até mesmo marginais na trajetória de desenvolvimento da Coreia do Sul, é negligenciar a existência de uma estratégia coesa de política econômica que conduziu o processo de estrutura de propriedade, organização industrial, centralização do capital e absorção de conhecimento tecnológico, visando fundamentalmente o desenvolvimento econômico de caráter nacional do país.

\section{Os quatro elementos fundamentais da política econômica coreana para o seu processo de desenvolvimento econômico}

A evolução do contexto histórico entre os anos 1940 e 1980, deixa nítido que o cenário externo foi favorável para que a Coreia do Sul pudesse 
lograr o desenvolvimento econômico com elevadas taxas de crescimento e profunda transformação estrutural. Entretanto, isso não significa afirmar que o cenário externo foi o fator determinante para tal fato, mas sim importante na medida em que o governo coreano utilizou de forma estratégica esse ambiente externo benéfico, adotando um modelo de desenvolvimento econômico em que a presença do Estado foi peça-chave na condução da política econômica que promovesse o crescimento e a transformação estrutural, materializado nos planos quinquenais implementados no país entre os anos 1960 aos anos $1980^{2}$. Entre os elementos do modelo adotado pela Coreia que deixam evidentes uma política Estatal-industrialista contrária a um modelo de desenvolvimento orientado pelos princípios do mercado, aponta-se aqui como determinantes: 1) a estrutura de propriedade do capital; 2) a organização empresarial; 3) a centralização do capital; e 4) o processo de absorção e desenvolvimento tecnológico.

Em primeiro lugar, a estrutura de propriedade do capital na economia coreana tem como uma das características principais a presença dos chaebols, grandes conglomerados empresarias privados nacionais familiares que atuam em diversos setores da economia, cuja relação com o governo foi decisiva no processo de implementação do modelo de desenvolvimento econômico do país. Essa relação vai implicar em uma estrutura de propriedade do capital em que as empresas estatais e os chaebols irão ser elementos fundamentais no processo de diversificação industrial orientado para as exportações, além de uma política de restrições ao investimento estrangeiro direto (IED).

Se no início dos anos 1960 predominava uma política menos restritiva para o ingresso de qualquer forma de capital estrangeiro, que permitia a entrada de subsidiárias estrangeiras no país sem grandes restrições, nos anos 1970 o governo adotou uma política mais restritiva, com maior controle sobre a entrada de investimento estrangeiro direto. Essa política de controle sobre o IED foi marcada nos anos 1970, principalmente, pela imposição de critérios tais como a proibição de

(2) No final desta seção tem dois quadros que resumem os planos quinquenais e as principais políticas implementadas para alcançar as metas dos planos quinquenais. 
empresas estrangeiras que concorressem com as empresas nacionais tanto no mercado interno como no mercado externo, exigência de performance exportadora aos IEDs que entrassem no país, além do índice de participação estrangeira ficar limitado a aproximadamente 50\%. Com isso, as empresas subsidiárias estrangeiras tiveram um papel complementar em setores pontuais, já que os grandes grupos nacionais chaebols atuaram nos setores considerados mais estratégicos da economia coreana (Kim, 2005a).

Essa centralização da propriedade dos ativos produtivos nos chaebols e nas empresas estatais está associada ao reconhecimento de que a Coreia tinha um mercado interno pequeno, de modo que a política de diversificação industrial estaria entrelaçada a uma política de desempenho exportador das grandes empresas, fortalecendo assim o ganho de economia de escala inerente às tecnologias maduras, com o país adquirindo ganhos de produtividade e se inserindo no comércio internacional através de grandes corporações multinacionais de forma mais competitiva.

Mesmo que nos anos 1980 passasse a predominar uma política de liberalização para o IED com a implementação do quinto plano quinquenal, ainda permaneceram na Coreia medidas restritivas que mantiveram o predomínio das grandes empresas nacionais no mercado coreano. Por exemplo, nos anos 1980, a participação dos subsetores industriais abertos ao capital estrangeiro sai de $44 \%$ em 1970 para $66 \%$ em 1984, além de substituir o "sistema de lista negativa" pelo "sistema de lista positiva", no qual o IED estaria aprovado em setores industriais em que antes essas empresas não poderiam entrar (KIM, 2005a). Sobre esse movimento que acontece nos anos 1980, dois fatores devem ser levado em consideração para que se compreenda que a decisão do governo coreano em adotar uma política de liberalização na estrutura de propriedade, está associado à própria estratégia do governo de avanço da estrutura industrial coreana: 1) como no $4^{\circ}$ Plano Quinquenal um dos objetivos principais era fazer com que a indústria coreana avançasse em setores mais intensivos em $\mathrm{P} \& \mathrm{D}$, o governo viu como estratégica a presença de investimentos estrangeiros diretos para desenvolverem a infraestrutura necessária para o fomento da ciência e tecnologia, assim como das atividades de P\&D; 2) além do mais, é importante considerar que esse processo de 
liberalização aconteceu quando a estrutural industrial coreana alcançou um nível de desenvolvimento suficiente para poder concorrer com empresas estrangeiras, tanto no mercado interno como também no mercado externo, não comprometendo assim a força da estrutura produtiva nacional (Kim, 1997).

Em segundo lugar, a política de estrutura de propriedade vai convergir com a política de organização industrial que predominou na Coreia do Sul, na medida em que os chaebols serão considerados aliados estratégicos e fundamentais. Os chaebols estarão presentes em todas as fases da industrialização coreana: como na fase da expansão da indústria leve nos anos 1960; nos anos 1970 com a construção das indústrias pesadas e químicas; e nos anos 1980 os chaebols foram decisivos na expansão e intensificação dos setores mais intensivos nas atividades de P\&D. Na verdade, o governo coreano enxerga nos chaebols uma importante fonte de acumulação de capital e tecnologia, ou seja, como um elemento central que poderia possibilitar um processo de industrialização com ganhos de economia de escopo e upgrading tecnológico, associado à interiorização do processo de desenvolvimento tecnológico (Kim, 1997; 2005b).

A expansão dos chaebols estava relacionada a uma política de diversificação e direcionamento para o comércio exterior. A amplitude da diversificação se torna clara quando observamos que a atuação das grandes empresas coreanas é direcionada para diversos setores, tais como o setor de serviços financeiros, construção, as indústrias leve e pesada, assim como nos setores mais intensivos em tecnologia e em P\&D. Esse processo de diversificação das grandes empresas sempre esteve associado a um conjunto de políticas de incentivos, subsídios e de reserva de mercado que beneficiou os chaebols, fato este que foi mais intenso nos anos $1970 \mathrm{com}$ o $3^{\circ}$ plano quinquenal.

Outro elemento de política industrial adotado na Coreia que marcava a relação entre Estado e chaebols foram as políticas de metas de desempenho nas exportações e no aprendizado tecnológico, que eram estabelecidas pelo governo e que essas grandes corporações deveriam cumprir como exigência para que elas pudessem se beneficiar das políticas 
de incentivos do governo. Por mais que essa relação entre Estado e chaebols tenha passado por modificações nos anos 1980, com a redução da política de incentivos e subsídios, os chaebols continuaram a apresentar elevado crescimento e sem ininterrupção no direcionamento da diversificação, pois essas empresas passaram a atuar em setores altamente intensivos em tecnologia como eletroeletrônicos e participaram de forma ativa no processo de privatização bancária nos anos 1980, com muitos chaebols adquirindo bancos e passando a atuar mais ainda no setor financeiro.

Como resultado do processo de expansão e diversificação dos chaebols direcionados para o comércio externo, a Coreia apresentou um elevado upgrading na qualidade da pauta exportadora em sua inserção no comércio internacional, como mostra a Tabela 1 . Como pode ser visto, a participação das exportações no PIB sai de 13,2\% em 1970 e salta para um percentual de 35,6\% em 1988. Esse crescimento da participação das exportações no PIB está associado a uma transformação profunda na qualidade da pauta exportadora, tendo em vista que a participação de produtos da indústria primária de baixa intensidade tecnológica sai de 17,5\% em 1970 e cai para 5,3\% em 1989, enquanto a participação dos produtos das indústrias pesada e química mais intensivos em tecnologia sai de uma participação de 12,8\% em 1970 e alcança o percentual de 55,4\% em 1989.

Tabela 1

Participação das exportações no PIB e participação segundo setores nas exportações Coreia do Sul - Anos 1970 e 1980

\begin{tabular}{ccccc}
\hline Ano & Exportações/PIB & $\begin{array}{c}\text { Indústria } \\
\text { Primária/Exportações }\end{array}$ & $\begin{array}{c}\text { Indústrias Pesada } \\
\text { e Química/Exportações }\end{array}$ & $\begin{array}{c}\text { Indústria } \\
\text { Leve/Exportações }\end{array}$ \\
\hline $\mathbf{1 9 7 0}$ & 13,2 & 17,5 & 12,8 & 69,7 \\
\hline $\mathbf{1 9 7 3}$ & 27,9 & 12,8 & 23,8 & 63,4 \\
\hline $\mathbf{1 9 7 7}$ & 29,7 & 18,0 & 35,0 & 47,0 \\
\hline $\mathbf{1 9 7 9}$ & 25,9 & 14,1 & 38,1 & 47,8 \\
\hline $\mathbf{1 9 8 0}$ & 31,2 & 11,7 & 41,8 & 46,4 \\
\hline $\mathbf{1 9 8 3}$ & 31,7 & 6,8 & 51,8 & 41,3 \\
\hline $\mathbf{1 9 8 6}$ & 35,1 & 6,1 & 51,9 & 42,0 \\
\hline $\mathbf{1 9 8 8}$ & 35,6 & 5,5 & 55,4 & 39,1 \\
\hline $\mathbf{1 9 8 9}$ & 30,2 & 5,3 & 55,4 & 39,3 \\
\hline
\end{tabular}

Fonte: Banco da Coreia (www.ecos.bok.or.kr). 
Esse ganho de qualidade na pauta exportadora coreana foi primordial para a continuidade do elevado crescimento econômico e transformação estrutural do país. Laplane; Ferreira; Borghi (2013) afirmam que um ponto a ser ressaltado é a importância do upgrading na qualidade da pauta exportadora como variável fundamental no processo de orientação exportadora, principalmente visando impedir uma restrição de balanço de pagamentos ao crescimento econômico. Como a Coreia tinha uma limitação em recursos naturais - que, além de não constituírem fonte de receitas de exportação, precisavam também ser importados -, e a importação de bens de capital e insumos intermediários eram essenciais para lograr os objetivos dos planos quinquenais de expandir e aprofundar a estrutural industrial do país, a exportação de produtos mais intensivos em tecnologia seria essencial para gerar divisas e propiciar o equilíbrio nas contas externas do país, sem restringir o elevado crescimento econômico. Segundo os autores, isso possibilitava tanto à indústria doméstica operar em plena capacidade, quanto o financiamento das importações de bens de capital. Entretanto, a expansão das exportações de produtos mais intensivos em tecnologia estava associada a necessidade de construir nova capacidade produtiva e de ganhos de produtividade que possibilitassem a Coreia manter a sua competitividade na economia internacional.

É importante considerar o regime de fiscalização imposto pelo Estado sobre a atuação dos grandes chaebols. As empresas que apresentavam bom desempenho eram recompensadas com mais crédito com juros baixos, licenças nos setores industriais mais lucrativos propiciando melhores condições para a diversificação, subsídios e isenções. Por outro lado, as empresas que não cumpriam as metas com baixo desempenho ou até mesmo não direcionavam seus recursos para os setores considerados estratégicos pelo Estado eram punidas com suspensão do crédito, não renovava seus empréstimos, suspendia os subsídios e isenções, entre outras punições. Essa política ficou conhecida na literatura como "picking winners and punishing losers", a qual tem como característica implementar um padrão seletivo da "escolha de vencedores" (picking winners) e "punição dos perdedores" (punishing losers), utilizando como parâmetros para essa política variáveis como metas de exportação, autonomização tecnológica na fabricação, a redução de preços 
locais e/ou melhor qualidade, inserção internacional, geração de empregos, etc. Nessa estratégia, os critérios de decisão governamental são fundamentais no dinamismo desse mecanismo de política industrial para manter uma relação de coerência quanto a recompensa e punições, respostas e estímulos (Canuto, 1993).

A resultante do crescimento e diversificação dos chaebols, facilitada pela sua relação com o Estado, tem consequências imediatas características específicas na configuração da organização industrial da economia coreana, pois com uma estrutura industrial dominada por essas grandes empresas o mercado coreano passou a ser altamente concentrado, com pequenas e médias empresas tendo pouco espaço no país. Segundo Kim (2005a), um exemplo da alta concentração que predominou no país é o fato de que em 1977, 93\% de todas as mercadorias e $62 \%$ de todas as vendas foram produzidas em condições de monopólio, duopólio ou oligopólio, sendo que os três maiores produtores eram responsáveis por mais de $60 \%$ de participação no mercado. Além do mais, os dez maiores chaebols foram responsáveis por 48,1\% do PNB em 1980, ficando evidente o alto nível de concentração de mercado e o poder dos chaebols na Coreia do Sul.

Em terceiro lugar, a política de centralização do capital será um aspecto chave na trajetória de desenvolvimento da Coreia do Sul. Primeiro porque quando se considera a política de aprofundamento industrial ficava evidente que seria necessária uma elevada taxa de investimento, exigindo assim um alto volume de crédito. Com isso, considerando que a Coreia do Sul é um país de industrialização tardia dependente dos recursos externos, o governo coreano adotou uma estratégia de vincular o crédito externo com o crédito interno para financiar os planos de desenvolvimento. Nesse sentido, o governo coreano implementou uma política de controle das instituições financeiras, controle sobre as taxas de juros e sobre a distribuição dos recursos financeiros para direcionar o crédito de acordo com as estratégias de cada momento histórico do país. Essa política de distribuição de recursos sempre esteve associada aos objetivos dos planos de desenvolvimento econômico, de modo que os setores eram selecionados estrategicamente e sempre voltados para a orientação exportadora. 
O sistema financeiro coreano começou a ser montado já no período da colonização japonesa. Durante esse período, o fato mais marcante foi a criação do Industrial Bank of Chosen (IBC), cujo objetivo principal era financiar projetos industriais e de serviços públicos. Com o fim do domínio japonês sobre a Coreia, início da ocupação americana e o período da Guerra da Coreia, todas as propriedades japonesas foram repassadas para o governo americano, inclusive as incipientes instituições financeiras. Nesse período, o Industrial Bank Of Chosen (IBC) passou a ser o Bank Of Korea (BOK) - Banco Central da Coreia. Os anos 1950 serão marcados também pelo processo de privatização dos bancos, uma exigência do governo americano. Ao mesmo tempo em que houve as privatizações, foram criados em 1954 o Korea Development Bank (KDB) Banco de Desenvolvimento da Coreia - com a função de garantir o crédito de médio e longo prazo para o desenvolvimento industrial, e o Korea Agriculture Bank (KAB) - Banco da Agricultura - com o intuito de criar fundos para o financiamento da pesca e agricultura. Mesmo considerando os avanços nos anos 1950 no sistema financeiro coreano, o fato notório para esse período é que a ajuda externa dos EUA foi a principal fonte de recursos para suprir as necessidades de importações requeridas pelos investimentos do país durante essa fase, o que deixa evidente a fragilidade das condições internas de financiamento ainda durante esse período (Castro, 2006).

Os anos 1960 foram marcados pelo processo de reestatização do sistema bancário, fazendo com que o comando estatal predominasse tanto sobre os fluxos de crédito interno como também externo, com o objetivo de financiar o processo de industrialização. Foi construída através do Estado uma estratégia de articulação do financiamento externo com o financiamento interno para financiar os planos quinquenais. Além da reestatização dos bancos, do fortalecimento do Bank Of Korea (BOK), do Korea Development Bank (KDB), o governo coreano criou o National Agriculture Cooperatives Federation (NACF) e o Medium Industry Bank (MIB), os quais foram essenciais para ampliar o fornecimento de empréstimos para as empresas. O governo coreano conseguiu estabelecer o comando estatal sobre os fluxos de crédito interno e externo para financiar as empresas, acumulando recursos suficientes para ampliar o volume de 
crédito para manter as taxas de investimentos elevadas suficientemente para cumprir os objetivos dos planos quinquenais (Castro, 2006).

Durante esse período os bancos eram estatais e o Estado exercia forte controle sobre os créditos externo e interno. Diante da dificuldade de muitas empresas de terem acesso ao crédito no mercado internacional, o governo coreano utilizou o sistema de garantias para regular o acesso aos mercados internacionais de capital, direcionando o capital externo de acordo com os setores e os projetos de investimentos considerados mais importantes para a economia. Portanto, os anos 1960 e 1970 foram marcados por um processo de acumulação de capital direcionada pelo Estado, com o intuito de superar as dificuldades de uma economia de industrialização tardia, aliando a política de centralização de fundos investíveis de origem interna e externa através dos bancos nacionais, a uma política de alocação desses fundos para os setores selecionados pelos planos de desenvolvimento econômico (Canuto, 1994).

Com a crise dos anos 1980 houve uma profunda reversão da liquidez no sistema financeiro internacional. Nesse período, o governo coreano implementou uma reforma financeira em 1984 que tinha como principal característica a privatização do sistema bancário. Todavia, é importante observar que a privatização não significou desnacionalização do sistema bancário, tendo em vista que quem assumiu o controle acionário dos bancos em sua grande maioria foram os chaebols, trazendo à tona a relevante relação entre chaebols e Estado no processo de desenvolvimento econômico coreano.

O controle acionário dos bancos pelos chaebols foi importante diante do cenário externo dos anos 1980, pois para os credores internacionais a presença dos chaebols significava que a continuidade do financiamento era direcionada para estruturas produtivas multinacionais com forte inserção no comércio internacional, as quais possuíam elevadas receitas das exportações que davam garantias de honrar os compromissos externos do país. Além do mais, a privatização dos bancos não representou alteração substancial na capacidade de interferência e gestão do Estado sobre o sistema financeiro do país, tendo em vista que o Bank of Korea permaneceu com forte influência no direcionamento das instituições 
financeiras, principalmente quando constatamos que o Estado exerceu papel ativo no processo de reestruturação produtiva que ocorreu nos anos 1980 e, para isso, o Estado precisou exercer seu caráter de emprestador de última instância, função esta que só foi possível ser exercida pela continuidade da influência do governo no sistema bancário nacional (Canuto, 1994).

Em quarto lugar, a estrutura de propriedade, a organização industrial e a política de centralização do capital, quando articuladas de forma estratégica, resultaram em uma estratégia de absorção e desenvolvimento tecnológico imprescindível para o modelo de crescimento orientado para fora da Coreia do Sul. Isso é comprovado quando observamos que na estratégia de internalização de tecnologia se fazem presentes os mesmos agentes que fizeram possível a construção de uma estrutura de propriedade, organização industrial e centralização do capital singular no contexto dos países de industrialização tardia. A estratégia de absorção de tecnologia vai ter a presença da articulação entre o Estado, os grandes conglomerados chaebols e o sistema financeiro nacional, construindo assim todo um aparato institucional necessário para o upgrading tecnológico do país, já que no modelo de desenvolvimento orientado para fora adotado pela Coreia estava explícita a necessidade de uma inserção no comércio internacional em produtos com maior valor agregado.

$\mathrm{Na}$ literatura sobre o processo de internalização da tecnologia na Coreia, predomina a ideia de que o país adotou um modelo de imitação associado à engenharia reversa nos anos 1960 e nos anos 1970. Segundo Kim (2005a), a imitação é uma atividade de cópias ou clonagens de produtos originais, considerados legal que não envolve violação de patentes nem é pirataria de propriedade intelectual. A imitação não exige investimento especializado em $\mathrm{P} \& \mathrm{D}$, apenas um baixo nível de aprendizagem tendo em vista que não é necessário gerar novos conhecimentos. A imitação pode ser uma nova combinação de elementos tecnológicos altamente padronizados que pode ser aplicada através da engenharia reversa - que consiste em uma atividade que trabalha com um 
produto existente, identificando seu funcionamento, o que ele faz exatamente e como ele se comporta em todas as circunstâncias.

Nos anos 1980, o país transita para um modelo de imitação criativa, com atividades de Pesquisa e Desenvolvimento (P\&D). A imitação criativa, de acordo com Kim (2005a), está associada a cópias de projetos, adaptações criativas, saltos tecnológicos e adaptações. As imitações criativas visam a geração de cópias dos produtos, mas com novas características de desempenho, envolvendo assim não apenas parcerias de transferência de tecnologia, mas também um aprendizado específico por meio de grandes investimentos em atividades de P\&D para criar imitações, cujo desempenho pode superar o do produto original. A imitação criativa é uma estratégia de internalização de tecnologia no momento em que o país logra um estágio mais maduro no seu processo de industrialização, principalmente quando tem instituições dedicadas a Ciência e Tecnologia (C\&T) e Pesquisa e Desenvolvimento (P\&D).

A Coreia foi capaz de criar uma infraestrutura que possibilitou ao país trilhar uma trajetória tecnológica de um país de industrialização tardia, iniciando seu processo de absorção de conhecimento tecnológico pela imitação por engenharia reversa e depois por imitação criativa intensiva em P\&D. Para isso, a trajetória de desenvolvimento coreano foi essencial: a) ao adotar uma estratégia de industrialização export-driven industrialization, o governo obrigou as empresas nacionais, como condição de sua sobrevivência, a intensificarem seus investimentos em setores mais intensivos em tecnologia, assim como implementar técnicas de produção que promovessem economia de escala, para que essas empresas tivessem condições mais competitivas de concorrerem em um mercado mundial cada vez mais competitivo; b) o governo exerceu um impacto substancial no processo de aprendizado tecnológico através da implementação de medidas diretas e indiretas para a promoção do avanço industrial, do comércio e do desenvolvimento da ciência e tecnologia; c) a estrutura e a qualidade do sistema educacional coreano ofertando mão-deobra qualificada e disciplinada, foi essencial para fomentar a acumulação de capacidade tecnológica empresarial; d) e o ambiente sociocultural, abrangendo as normas e valores da sociedade, como o respeito a hierarquia 
e a disciplina no trabalho, promoveram um ambiente de formação ética do trabalho que influenciou a mentalidade e o comportamento das pessoas nas empresas.

A compreensão dessa estratégia de transição do modelo de imitação via engenharia reversa para o modelo de imitação criativa intensiva em P\&D da Coreia do Sul, passa pelo entendimento da relação entre os fatores já discutidos anteriormente: a) o cenário externo favorável; b) o papel do Estado; c) e a relação do Estado com os grandes grupos industriais coreanos, os chaebols. Sem essa conexão entre esses elementos, podemos afirmar que dificilmente a Coreia teria logrado o estágio tecnológico que alcançou.

O cenário externo foi favorável à Coreia do Sul e isso possibilitou a criação de uma relação política com países em estágios avançados de desenvolvimento, principalmente com o Japão e os EUA, os quais foram essenciais em fornecer fontes de financiamento e facilitar o processo de transferência de tecnologia. Na verdade, a relação com o Japão e os EUA foi importante tanto no processo de transferência de tecnologia, como também como mercados de destino para as exportações dos produtos coreanos, fato este que fica patente quando observamos que os principais parceiros comerciais da Coreia do Sul foram justamente esses dois países.

Por outro lado, o papel do Estado dirigente foi essencial. A sua essencialidade se faz presente no modelo de desenvolvimento adotado, um desenvolvimento industrial voltado para o comércio exterior que exigiu grande habilidade na condução da política econômica. Nesse sentido, o projeto estatal-industrialista coreano torna o papel do Estado fundamental no processo de absorção e internalização de tecnologia em duas dimensões: 1) a política de promoção das exportações; 2) e a construção de toda uma infraestrutura para o desenvolvimento da Ciência e Tecnologia $(\mathrm{C} \& \mathrm{~T})$ e a Pesquisa e Desenvolvimento (P\&D).

A construção da infraestrutura feita pelo Estado para o desenvolvimento do C\&T e P\&D tem como alicerce o investimento na educação. A estratégia de internalizar e absorver tecnologia através da importação de bens de capital, por exemplo, não seria possível sem a formação de uma infraestrutura que absorvesse todo conhecimento 
tecnológico necessário para realizar o processo de imitação e depois a imitação criativa, fortalecendo assim o ramo de bens de capital que é um dos mais intensivos em tecnologia.

Por fim, a aliança Estado-Chaebols colocou essas empresas em uma posição privilegiada no recrutamento de uma mão-de-obra com elevado nível de qualificação, com recursos organizacionais e tecnológicos suficientes para identificar, negociar, financiar, absorver e aperfeiçoar as transferências de tecnologias estrangeiras. Essas empresas exerceram papel essencial na expansão da indústria leve, das indústrias pesadas e químicas, e na expansão e intensificação das atividades intensivas em P\&D durante os anos 1980, ou seja, em todas as fases de industrialização da Coreia do Sul os chaebols foram atores essenciais (Lee, 2005; Kim, 2005b; 1997).

O desempenho dos chaebols na internalização e absorção de tecnologia fica constatado quando é analisado a expansão do ramo de bens de capital no país. Segundo Lee (2005), os chaebols lideraram o processo de aprendizado através da aquisição de bens de capital estrangeiro para, posteriormente, produzir internamente com o intuito de atender as demandas crescentes de aquisições por encomendas de máquinas locais e a fabricação direta de bens de capital para satisfazer as necessidades internas. Com isso, se ao final dos anos 1970 o índice de auto-suficiência ficou em torno de $30 \%$ a $40 \%$, deixando nítido que as empresas locais ainda não estavam aptas a produzir bens de capital avançados para atender o mercado interno, nos anos 1980 o índice de auto-suficiência chega a $60 \%$, mostrando que os chaebols corroboraram de forma crucial para a internalização da tecnologia.

Esse avanço no processo de ampliação e aprofundamento da pesquisa e do desenvolvimento na Coreia pode ser visualizado nos números da Tabela 2. As despesas em P\&D deram um salto na Coreia do Sul, saindo de 2,1 bilhões de wons em 1965 para 3.349 trilhões de wons em 1990. Essa expansão das despesas com P\&D está relacionada a um crescimento substancial da participação do $\mathrm{P} \& \mathrm{D}$ como proporção do $\mathrm{PNB}$, tendo em vista que a participação era de $0,26 \%$ em 1965 e saltou para $1,95 \%$ em 1990. Outro indicador que chama a atenção é o crescimento do número de pesquisadores que saiu de um total de 2.135 em 1965 para 
70.503 em 1990, uma taxa de crescimento de 70,4\% no número de pesquisadores. Isso será fundamental para o crescimento do número de pesquisadores por 10 mil habitantes, saindo de 0,7 em 1965 e salta para 16,4 em 1990. Portanto, fica nítido que a resultante da política para estimular a C\&T e P\&D foi a profunda transformação estrutural do parque industrial coreano, com o país intensificando suas exportações em produtos intensivos em tecnologia e se inserindo no comércio internacional de forma muito mais competitiva, vantagens competitivas estas dinâmicas e não estáticas.

Tabela 2

Despesas com Pesquisa e Desenvolvimento - Coreia do Sul 1965/1990 em bilhões de wons

\begin{tabular}{|c|c|c|c|c|c|c|}
\hline Descrição & 1965 & 1970 & 1975 & 1980 & 1985 & 1990 \\
\hline Despesas em P\&D & 2,1 & 10,5 & 42,7 & 282,5 & $1.237,1$ & $3.349,9$ \\
\hline Governo & 1,9 & 9,2 & 30,3 & 180,0 & 306,8 & 651,0 \\
\hline Setor Privado & 0,2 & 1,3 & 12,3 & 102,5 & 930,3 & $2.698,9$ \\
\hline P\&D/PNB & 0,26 & 0,38 & 0,42 & 0,77 & 1,58 & 1,95 \\
\hline \multicolumn{7}{|l|}{ Setor Industrial } \\
\hline Despesas em P\&D & ND & ND & 16,70 & 75,97 & 688,59 & $2.134,70$ \\
\hline Percentual de vendas & ND & ND & 0,36 & 0,50 & 1,51 & 1,96 \\
\hline Número de Pesquisadores * & 2.135 & 5.628 & 10.275 & 18.434 & 41.473 & 70.503 \\
\hline Governo/Instituições públicas & 1.671 & 2.458 & 3.086 & 4.598 & 7.542 & 10.434 \\
\hline Universidades & 352 & 2.011 & 4.534 & 8.695 & 14.935 & 21.332 \\
\hline Setor Privado & 112 & 1.159 & 2.655 & 5.141 & 18.996 & 38.737 \\
\hline Despesas em P\&D por Pesquisadores (milhares de wons) & 967 & 1.874 & 4.152 & 15.325 & 27.853 & 47.514 \\
\hline Número de pesquisadores por 10 mil habitantes & 0,7 & 1,7 & 2,9 & 4,8 & 10,1 & 16,4 \\
\hline Número de Centros de P\&D de Empresas & 0 & 1 & 12 & 54 & 183 & 966 \\
\hline
\end{tabular}

Fonte: Kim (2005a) - Ministério da Ciência e Tecnologia da Coreia, 1994 - Report on the Survey of R\&D in Science and Techonology. Seul: MCT, dezembro 1994.

* Os números não incluem assistentes de pesquisa, técnicos e equipes de apoio.

A análise dessas quatro dimensões das políticas internas da Coreia atesta a afirmação de Laplane, Ferreira e Borghi (2013), os quais chamam a atenção para o fato de que uma característica muito importante da trajetória de desenvolvimento da Coreia é a capacidade do governo de ter a flexibilidade para introduzir mudanças de rumo na sua política econômica, com o objetivo de atender às transformações experimentadas pela economia internacional em diversos momentos. Isso pode ser constatado nas iniciativas bem-sucedidas para redefinir a estratégia de desenvolvimento face às crises internacionais - como a do petróleo nos 
anos 1970 e da dívida externa nos anos 1980 - momentos estes em que a Coreia avança para o terceiro, quarto e quinto planos quinquenais.

Pode-se observar que o cenário externo favorável para a Coreia do Sul foi importante ao longo do seu processo de desenvolvimento. Entretanto, não se pode afirmar que foi determinante desconsiderando fatores internos que foram essenciais. Estes fatores internos estão inseridos na condução da política econômica do país com os planos de desenvolvimento econômico discutidos neste artigo, principalmente nos fatores aqui considerados como: 1) a estrutura de propriedade do capital; 2) a organização empresarial; 3) a centralização do capital; 4) e o processo de absorção e desenvolvimento tecnológico.

\section{Quadro 1}

Síntese dos principais planos quinquenais

\begin{tabular}{|c|c|c|}
\hline Planos & Objetivos & Resultados \\
\hline $\begin{array}{c}1^{\circ} \text { Plano Quinquenal } \\
\quad(1962-1966)\end{array}$ & $\begin{array}{c}\text { Promover a indústria leve,tais como fertilizantes e o } \\
\text { refino de petróleo. }\end{array}$ & $100 \%$ alcançados. \\
\hline $\begin{array}{c}2^{\circ} \text { Plano Quinquenal } \\
\quad(1967-1971)\end{array}$ & $\begin{array}{l}\text { Promover a indústria química, aço e máquinas - } \\
\text { para romper o círculo da pobreza e dependência } \\
\text { em direção a uma economia mais moderna e } \\
\text { competitiva no cenário internacional. }\end{array}$ & $\begin{array}{c}\text { Segundo o estudo do Banco Mundial (1977), os objetivos dos } 2^{\circ} \mathrm{e} \\
3^{\circ} \text { planos foram quase } 100 \% \text { alcançados, sendo que em alguns } \\
\text { setores foram até mesmo ultrapassados. }\end{array}$ \\
\hline $\begin{array}{c}3^{\circ} \text { Plano Quinquenal } \\
\quad(1972-1976)\end{array}$ & $\begin{array}{c}\text { Avanço da indústria pesada e química, aliado a um } \\
\text { desenvolvimento integrado do território nacional } \\
\text { com equilibrio regional e redução das diferenças } \\
\text { entre áreas rurais e urbanas. }\end{array}$ & $\begin{array}{l}\text { Segundo o estudo do Banco Mundial (1977), os objetivos dos } 2^{\circ} \mathrm{e} \\
3^{\circ} \text { planos foram quase } 100 \% \text { alcançados, sendo que em alguns } \\
\text { setores foram até mesmo ultrapassados. }\end{array}$ \\
\hline $\begin{array}{c}4^{\circ} \text { Plano Quinquenal } \\
\quad(1977-1981)\end{array}$ & \begin{tabular}{|c|} 
Continuidade do alto padrão de crescimento aliado \\
à transformação estrutural da economia, com \\
ênfase nos setores mais intensivos em tecnologia. \\
Promover a substituição de importações em setores \\
como aço e produtos químicos, para garantir o \\
fornecimento adequado de bens intermediários para \\
a indústria de exportação. Eliminar o déficit em \\
transacões correntes. \\
\end{tabular} & $\begin{array}{l}\text { Para Chang (1994), os resultados das indústrias leve, pesada e } \\
\text { química mostram que houve na Coreia do Sul uma profunda } \\
\text { transformação estrutural, com o quarto plano quinquenal logrando } \\
\text { praticamente todos os seus objetivos. }\end{array}$ \\
\hline $\begin{array}{c}5^{\circ} \text { Plano Quinquenal } \\
\quad(1982-1986)\end{array}$ & $\begin{array}{c}\text { Promover a estabilidade da economia, aumento da } \\
\text { competitividade no comércio internacional através } \\
\text { da abertura da economia, obtenção de superávit } \\
\text { comercial, criação de emprego, aumento da renda } \\
\text { e desenvolvimento com maior equilibrio entre } \\
\text { classes. Para Kim (1997), o novo plano colocou } \\
\text { como meta dois principais objetivos: a promoção } \\
\text { de um maior bem estar social e a políticas de } \\
\text { promoção para o comércio exterior. }\end{array}$ & $\begin{array}{l}\text { Pode-se afirmar que muitas das metas foram alcançadas, } \\
\text { principalmente em relação ao avanço e aprofundamento do parque } \\
\text { industrial coreano, com as indústrias mais intensivas em tecnologia - } \\
\text { como automóveis, eletroeletrônica e semicondutores - passando a ser } \\
\text { líderes de crescimento econômico e como principais setores } \\
\text { exportadores. Maior abertura da economia coreana com reduções de } \\
\text { barreiras tarifárias e não-tarifárias; promoveu a abertura financeira, } \\
\text { mas com o governo não dando autonomia gerencial por completo ao } \\
\text { setor financeiro, o que irá resultar em um setor financeiro ainda } \\
\text { regulamentado pelo governo. As chaebols continuam com elevado } \\
\text { poder de mercado. Avanços nos indicadores sociais. }\end{array}$ \\
\hline
\end{tabular}

Fonte: Elaboração própria. 
Quadro 2

Principais políticas industriais e de ciência e Tecnologia - Coreia do Sul

\begin{tabular}{|c|c|c|}
\hline Categorias & Décadas de 1960 e 1970 & Década de 1980 \\
\hline Políticas Industriais & $\begin{array}{l}\text { Promoção deliberada das grandes empresas. } \\
\text { Orientação para a exportação. } \\
\text { Promoção das indústrias químicas e pesadas. } \\
\text { Repressão de movimentos trabalhistas para manter } \\
\text { a paz no setor industrial. }\end{array}$ & $\begin{array}{l}\text { Promoção de Pequenas e Médias Empresas. } \\
\text { Orientação para a exportação. } \\
\text { Políticas antitruste e de comércio equitativo. } \\
\text { Liberalização do comércio exterior. } \\
\text { Liberalização financeira. } \\
\text { Proteção dos direitos de propriedade Intelectual. } \\
\text { Mudança de ênfase para a P\&D e para o } \\
\text { desenvolvimento de mão-de-obra especializada. } \\
\end{array}$ \\
\hline $\begin{array}{c}\text { Política de Ciência e } \\
\text { Tecnologia }\end{array}$ & $\begin{array}{l}\text { Restrição aos Investimentos Estrangeiros Diretos e ao } \\
\text { ao Licenciamento de Tecnologia Estrangeira. } \\
\text { Promoção da Importação de Bens de Capital. } \\
\text { Promoção dos Institutos de Pesquisa do Governo em } \\
\text { vez da pesquisa nas Universidades. }\end{array}$ & $\begin{array}{l}\text { Promoção dos Investimentos Estrangeiros Diretos } \\
\text { e do Licenciamento de Tecnologia Estrangeira. } \\
\text { Ampla redes de difusão. } \\
\text { Promoção da pesquisa nas universidades. } \\
\text { Promoção das atividades de P\&D nas empresas. } \\
\text { Promoção de projetos de P\&D nacionais. }\end{array}$ \\
\hline
\end{tabular}

Fonte: Apud Kim (2005a, p. 83).

\section{Conclusão}

A performance de crescimento econômico, transformação estrutural e uma estratégia de inserção externa concentrada em produtos mais intensivos em tecnologia da Coreia do Sul, só foi possível pela peculiaridade da estratégia de política econômica interna. Entre os anos 1960 e 1980, embora o cenário externo tenha sido favorável para a Coreia do Sul, o que de fato determinou o sucesso da implementação dos planos quinquenais foi a condução de forma coesa das políticas relacionadas a estrutura de propriedade, organização industrial, centralização financeira e a estratégia de absorção de conhecimento tecnológico. Nos anos 1960 e 1970, a política de estrutura de propriedade impôs restrições ao investimento estrangeiro direto para defender as empresas nacionais, dando condições a essas empresas de se fortalecerem e ter poder de concorrência no mercado interno e externo. Essa política estava estreitamente associada a política de organização industrial, com a expansão dos grandes chaebols, em especial nos setores eletrônicos, automobilístico, naval, ferroviário e semicondutores. Essas empresas atuam com alto nível de concentração de mercado e, ao mesmo tempo, a estratégia de diversificação da sua atuação. 
Para sustentar essa política de controle da entrada e atuação do investimento estrangeiro direto e suporte para as grandes empresas expandirem a sua atuação em direção a setores mais intensivos em tecnologia, foi fundamental a concessão de crédito subsidiado e de longo prazo. Isso foi feito através da política de centralização do capital, com os bancos estatais, juntamente com o Korea Development Korea (KDB) e o Bank Of Korea (BOK), entre outras instituições e ministérios, atuando de forma centralizada direcionada pelo Estado para conceder os créditos necessários para as empresas e setores selecionados para que os objetivos dos planos quinquenais fossem alcançados. Com o fortalecimento dessas empresas através da política de estrutura de propriedade e organização industrial em um cenário com elevada concessão de crédito, essas empresas foram essenciais no processo de absorção de conhecimento tecnológico através da imitação criativa, com o governo criando vários institutos de pesquisa, assim como ampliando os investimentos na educação e formação de mão-de-obra qualificada.

Nos anos 1980, mesmo com cenário externo sendo favorável a Coreia do Sul, predominou a continuidade da condução de forma coesa da estratégia das políticas de estrutura de propriedade, organização industrial, centralização financeira e absorção de conhecimento tecnológico. A condução dessas políticas nos anos 1980 estava associada a um novo ambiente internacional e interno, com foco principal na necessidade do país avançar em setores industriais mais intensivos em $P \& D$, de modo que a conduta da política de desenvolvimento estava intrinsecamente atrelada a essa nova estratégia que fazia parte do $5^{\circ}$ plano quinquenal. Portanto, se na política de estrutura de propriedade o governo adotou medidas de liberalização retirando a maioria dos incentivos para o comércio exterior, quando consideramos a política de proteção da Coreia com outros países, podemos constatar que ainda predominou uma proteção em setores considerados estratégicos pelo governo. Além do mais, a política mais aberta do governo para o IDE teve como objetivo induzir a transferência de novas tecnologias mais sofisticadas e promover a concorrência no mercado, para que as empresas nacionais intensificassem suas atividades 
de inovação como parte da nova estratégia de absorção de conhecimento tecnológico através da imitação criativa intensiva em P\&D.

Em relação à política de organização industrial, mesmo com plano de coordenação de investimentos e de programas de reestruturação industrial realizados na década de 1980 para ajudar setores e reduzir o poder de mercado dos grandes chaebols, essas empresas continuaram com forte influência na economia coreana atuando em diversos setores, como no setor financeiro, e permaneceram como elementos essenciais no processo de desenvolvimento do ramo de bens de capital, na medida em que as empresas usuárias locais da Coreia do Sul passaram a apresentar uma crescente aquisição por encomenda de máquinas locais, assim como da fabricação direta de bens de capital para satisfazer as necessidades internas.

Na dimensão das reformas na política de centralização do capital, embora grande parte dos bancos comerciais tenham se tornado propriedade privada depois de meados dos anos 1980, o governo não deu autonomia gerencial por completo, o que irá resultar em um setor financeiro ainda regulamentado pelo governo. Além do mais, grande parte dos bancos foi adquirida pelos chaebols, o que resultou em um mercado financeiro ainda predominantemente nacional. Por fim, a nova estratégia de absorção de conhecimento tecnológico transitou para a imitação criativa intensiva em $\mathrm{P} \& \mathrm{D}$, com a Coreia fazendo ajustes estruturais e adquirindo progressivamente mais indústrias intensivas em tecnologia, com o governo passando a dedicar mais atenção às atividades locais de $P \& D$ através políticas de estímulo aos investimentos diretos em $\mathrm{P} \& \mathrm{D}$ e pacotes de incentivos.

Nos anos 1980, com a Coreia dando continuidade à sua estratégia de elevado crescimento econômico associado a profunda transformação estrutural - principalmente direcionando sua atividade produtiva para produtos mais intensivos em tecnologia e uma inserção internacional mais competitiva - o país logrou o objetivo de ter um parque industrial diversificado e concentrado em setores intensivos em tecnologia com ganho de market-share no mercado internacional. Os resultados do processo de desenvolvimento econômico da economia coreana provocam 
inevitavelmente análises comparativas em relação a outras economias de industrialização tardia, principalmente com os países da América Latina, e mais particularmente em relação ao Brasil.

Esse exercício pode ser feito utilizando as dimensões da estrutura de propriedade, organização industrial, centralização do capital e estratégia de absorção de conhecimento tecnológico, que são discutidos para o entendimento do sucesso coreano em sua trajetória de desenvolvimento econômico e podem ser usados para a realização de um estudo comparativo entre o Brasil e a Coreia, principalmente ampliando o espaço temporal para os anos 1990 e 2000.

\section{Referências bibliográficas}

AMSDEN. A. Asia's next giant. South Korea and late industrialization. New York: Oxford University Press, 1989.

BALASSA, Bela. Development strategies and economic performance: a comparative analysis of eleven semi-industrial economies. In: BALASSA, Bela (Org). Development strategies in semi-industrial economies. London: World Bank - The Johns Hopkins University Press, 1982.

CANUTO, Otaviano. Brasil e Coréia do Sul: os (des)caminhos da industrialização tardia. São Paulo: Nobel, 1994.

CANUTO, Otaviano. Aprendizado tecnológico na industrialização tardia. Economia e Sociedade, Campinas, n. 2, p. 171-189, 1993.

CARDOSO DE MELLO, J. M. (1975). O capitalismo tardio. São Paulo: Brasiliense, 1987.

CASTRO, Lavinia Barros. Financiamento do desenvolvimento: experiência coreana (1950-80) e reflexões comparativas ao caso brasileiro. Rio de Janeiro: UFRRJ, 2006.

CHANG, Ha-Joon. The political economy of industrial policy. London: Macmillan Press Ltd., 1994. 
COUTINHO, Luciano. Coréia do Sul e Brasil: paralelos, sucessos e desastres. In: FIORI, José Luís (Org.). Estados e moedas no desenvolvimento das nações. Rio de Janeiro: Vozes, 1999.

$\mathrm{CHO}$, Yoo Je. The international environment and Korea's economic development during 1950s-1970s. Research Series on International Affairs, v. 2, 2001.

CUMINGS, Bruce. The origins and development of the Northeast Asian political economy: industrial sectors, product cycles, and political consequences. In: DEYO, Frederic. The political economy of the new Asian industrialism. London: Cornell University Press, 1987.

JO, Y. Hugh. The capitalist world-system and Us Cold War policies in the core and the periphery: a comparative analysis of post-World War II American natio-building in Germany and Korea. American Sociological Association, v. 17, n. 2, 2011.

KIM, Eun Mee. Big business, strong state. Collusion and conflict in South Korean development, 1960-1990. New York: State University of New York Press, 1997.

KIM, Linsu. Da imitação à inovação. A dinâmica do aprendizado tecnológico da Coréia. Campinas: Editora da Unicamp, 2005a.

KIM, Linsu. O Sistema Nacional de Inovação Sul-Coreano em transição. In: KIM, Linsu; NELSON, Richard R. (Org.). Tecnologia, aprendizado e inovação. As experiências das economias de industrialização recente. Campinas: Editora da Unicamp, 2005b.

LAPLANE, Mariano. F.; FERREIRA, Adriana. N.; BORGHI, Roberto A. Z. Padrões de crescimento, investimento e processos inovadores: o caso da Coreia do Sul. In: Centro de Gestão e Estudos Estratégicos (CGEE). Padrões de desenvolvimento econômico (1950-2008): América Latina, Ásia e Rússia. Brasília: CGEE, 2013. v. 2. Disponível em: http://www.cgee.org.br/publicacoes/pde.php. Acesso: 10 fev. 2017.

LEE, Kong Era. O aprendizado tecnológico e o ingresso de empresas usuárias de bens de capital na Coréia do Sul. In: KIM, Linsu; NELSON, 
Richard R. (Orgs.). Tecnologia, aprendizado e inovação. As experiências das economias de industrialização recente. Campinas: Editora da Unicamp, 2005.

MEDEIROS, Carlos Aguiar. Globalização e a inserção internacional diferenciada da Ásia e da América Latina. In: TAVARES, Maria C.; FIORI, José L. (Org.). Poder e dinheiro. Uma economia política da globalização. Rio de Janeiro: Vozes, 1997.

MELLO, J. M. C. O capitalismo tardio - Contribuição à revisão crítica da formação e do desenvolvimento da economia brasileira. São Paulo: Editora Brasiliense, 1975 [1982].

OLIVEIRA, Carlos Alonso B. Processo de industrialização. Do capitalismo originário ao atrasado. São Paulo: Unesp, 1985 [2002].

TAVARES, M. C. Acumulação de capital e industrialização no Brasil. Campinas: Editora da Unicamp, 1974 [1985].

WESTPHAL, Larry E.; KIM, Linsu. Korea. Incentive policies and economic development. In: BALASSA, Bela (Org). Development strategies in semi-industrial economies. London: World Bank - The Johns Hopkins University Press, 1982.

WORLD BANK. Korea: appraisal of the heavy machinery project. v. I-II: Main report. Washington: The World Bank, 1977. (World Bank Discussion Papers). Disponível em: http://documents.worldbank.org/curated/en/1977/05/748613/korea-heavymachinery-project-vol-1-2-main-report. Acesso em: 9 out. 2011

WORLD BANK. Korea: managing the industrial transaction. Washington: World Bank, 1987. v. 1-2.

WORLD BANK. The East Asian miracle. Economic growth and public policy. New York: Oxford University Press, 1993. v. 1-2. (World Bank Policy Research Report). 